\title{
Well-Preserved Boundaries
}

Cappadocia was a place of cohabitation of Christians and Muslims until the GrecoTurkish Population Exchange (1923) terminated the Christian presence in the region. Using an interdisciplinary approach drawing on history, political science and anthropology, this study investigates the relationship between tolerance, cohabitation and nationalism. Concentrating particularly on Orthodox-Muslim and OrthodoxProtestant practices of living together in Cappadocia during the last fifty years of the Ottoman Empire, it responds to the prevailing romanticism about the Ottoman way of handling diversity. The study also analyzes the transformation of the social identity of Cappadocian Orthodox Christians from Christians to Greeks, through various mechanisms including the endeavor of the elite to utilize education and the press, and through nationalist antagonism during the long war of 1912 to 1922.

Gülen Göktürk received her Ph.D. in Political Science and Public Administration at Middle East Technical University, Turkey. She currently works as an Assistant Professor at Eskisehir Osmangazi University, Turkey. Her research interests include nationalism studies and Ottoman non-Muslim communities. 


\section{Birmingham Byzantine and Ottoman Studies}

\section{General Editors}

Leslie Brubaker

Rhoads Murphey

John Haldon

Birmingham Byzantine and Ottoman Studies is devoted to the history, culture and archaeology of the Byzantine and Ottoman worlds of the East Mediterranean region from the fifth to the twentieth century. It provides a forum for the publication of research completed by scholars from the Centre for Byzantine, Ottoman and Modern Greek Studies at the University of Birmingham, and those with similar research interests.

For a full list of titles in this series, please visit www.routledge.com/series/ BBOS

\section{The Cult of St Anna in Byzantium}

Eirini Panou

\section{Eastern Trade and the Mediterranean in the Middle Ages}

Pegolotti's Ayas-Tabriz Itinerary and its Commercial Context

Tom Sinclair

\section{The Eloquence of Art}

Essays in Honour of Henry Maguire

Andrea Olsen Lam and Rossitza Shroeder

\section{Iconophilia}

Politics, Religion, Preaching and the Use of Images in Rome, c.680-880

Francesca Dell'Acqua

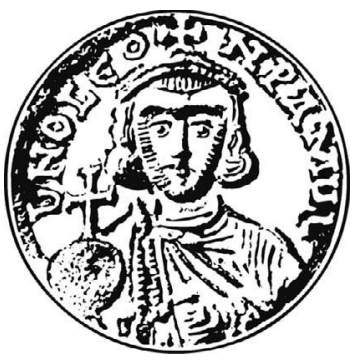

Centre for Byzantine, Ottoman and Modern Greek Studies University of Birmingham 


\section{Well-Preserved Boundaries}

Faith and Co-Existence in the Late Ottoman Empire

\section{Gülen Göktürk}

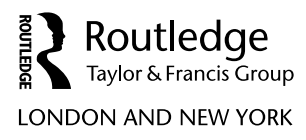


First published 2020

by Routledge

2 Park Square, Milton Park, Abingdon, Oxon OX14 4RN

and by Routledge

52 Vanderbilt Avenue, New York, NY 10017

Routledge is an imprint of the Taylor \& Francis Group, an informa business

\section{2020 Gülen Göktürk}

The right of Gülen Göktürk to be identified as author of this work has been asserted by her in accordance with sections 77 and 78 of the Copyright, Designs and Patents Act 1988.

All rights reserved. No part of this book may be reprinted or reproduced or utilised in any form or by any electronic, mechanical, or other means, now known or hereafter invented, including photocopying and recording, or in any information storage or retrieval system, without permission in writing from the publishers.

Trademark notice: Product or corporate names may be trademarks or registered trademarks, and are used only for identification and explanation without intent to infringe.

British Library Cataloguing-in-Publication Data

A catalogue record for this book is available from the British Library

Library of Congress Cataloging-in-Publication Data

Names: Göktürk, Gülen, author.

Title: Well-preserved boundaries : faith and co-existence in the late

Ottoman Empire / Gülen Göktürk. Description: First edition. | New York

: Routledge, 2020.

Series: Birmingham Byzantine and Ottoman studies ; volume 28 |

Includes bibliographical references and index.

Identifiers: LCCN 2020004621 (print) | LCCN 2020004622 (ebook) |

ISBN 9780367273385 (hardback) | ISBN 9780429296253 (ebook)

Subjects: LCSH: Cappadocia (Turkey)-History. | Cappadocia (Turkey)-

Ethnic relations. | Religious tolerance-Turkey-Cappadocia-History. |

Nationalism-Turkey-Cappadocia-History. | Toleration-Turkey-

Cappadocia-History. | Turkey-History-1878-1909. | Turkey-History-

20th century. | Turkey-History-Ottoman Empire, 1288-1918.

Classification: LCC DS156.C3 G65 2020 (print) |

LCC DS156.C3 (ebook) | DDC 305.6/81949509564109034-dc23

LC record available at https://lccn.loc.gov/2020004621

LC ebook record available at https://lccn.loc.gov/2020004622

Birmingham Byzantine and Ottoman Studies Volume 28

ISBN: 978-0-367-27338-5 (hbk)

ISBN: 978-0-429-29625-3 (ebk)

Typeset in Times New Roman

by Swales \& Willis, Exeter, Devon, UK 
To my parents 
$\because$ Taylor \& Francis

Taylor \& Francis Group

http://taylorandfrancis.com 


\section{Contents}

List of figures viii

Acknowledgments $\quad \mathrm{x}$

Introduction 1

1 Ottoman tolerance reconsidered 19

2 Maintaining boundaries: Faith and co-existence in late Ottoman $\begin{array}{ll}\text { Cappadocia } & 41\end{array}$

3 The path toward nationalism $\quad 74$

$4 \quad$ Halasane ta pragmata (Things spoiled) 115

5 Tolerating the heretics: The distinctive case of the Greek Protestants 131

$\begin{array}{ll}\text { Conclusion } & 155\end{array}$

$\begin{array}{lr}\text { Bibliography } & 161\end{array}$

$\begin{array}{lr}\text { Index } & 173\end{array}$ 


\section{Figures}

0.1 The Exchange Memorial at Neokaisaria. On its stone panel is written: "The live memory of Neokaisaria. Here and there. Never forgotten!” Photograph: Gülen Göktürk

0.2 Flyers of the fifteenth and sixteenth pan-Greek Gavoustima of Cappadocians organized by the "Cultural Society of Misti" and the "Asia Minor Society of Neokaisaria, Ioannina," respectively. I owe thanks to both societies for providing me with the posters of the Gavoustima gathering they organized

0.3 The Hasatani family in their local costumes, Sille, Konya. Source: Prodromos B. Spyrakos. Permission granted by the family

0.4 Map of Central and Southern Anatolia. Source: H'E $\xi o \delta o \varsigma ~ \tau o ́ \mu \varsigma \varsigma$ B' (The Exodus Volume 2). Permission granted by Centre for Asia Minor Studies

1.1 A depiction showing Mehmed II presenting his "lost" berat to Patriarch Gennadius II. The Greek Orthodox Patriarchate, İstanbul. Photograph: Gülen Göktürk

2.1 Kayabaş1: An Orthodox Christian neighborhood in nineteenth-century Niğde. Photograph: Gülen Göktürk

2.2 A Greek-speaking Orthodox family from Ürgüp (Prokopi) in the late nineteenth century. Source: Photography Archive of Centre for Asia Minor Studies

2.3 An inscribed stone panel of a house door from Cappadocia: "the house of Tylkiar Anastas, Masallah, 1871.” Photograph: Gülen Göktürk

2.4 The wedding ceremony of Rahil Loukopoulou in Nevşehir. Source: Photography Archive of Centre for Asia Minor Studies

2.5 St.Vasilis Church of Misti (Çarıklı) Niğde. The construction of the church was completed in 1922. The Orthodox Community of the village could only use it for two years (Karalidis, 2005, p. 99). It is 
enormous for the size of the village community at the time.

Photograph: Gülen Göktürk

3.1 Tombstone of a tavern keeper's wife from Niğde in Karamanlidika in the yard of Zoodokhos Pigi Monastery in Istanbul. "In this tomb lies tavern keeper Savva's wife H. Vithleem from the village Iloson of Niğde. May god have mercy her soul. July 21, 1897."

Photograph: Gülen Göktürk

3.2 Greek language teacher Phillippos Papagrigoriou Aristovoulos in Nevşehir. Source: Photography Archive of Centre for Asia Minor Studies

3.3 Teachers and graduates of the Theological Seminary (1908-1909). Source: Photography Archive of Centre for Asia Minor Studies

5.1 Greek students of the American College in Talas with their Greek teacher, H. Bogdanos (third from right, seated) and next to him, the American director. Source: Photography Archive of the Centre for Asia Minor Studies

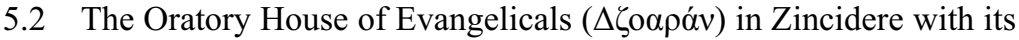
congregation on the left (Source: Agapidis, 1950) and its current state on the right. Photograph: Gülen Göktürk

5.3 The American Hospital in Talas. Source: The Missionary Herald, 1914

5.4 Anatolia College, Merzifon. Source: The Missionary Herald, 1921 


\section{Acknowledgments}

I am deeply grateful to Prof. Onur Yildırım for his support and encouragement at every step in my academic life thus far. I still remember the very first time I knocked on his door in 2005 as a sophomore who wanted to become an academician. From that moment on he shared his knowledge and experience with me. Through times when I felt discouraged by unlucky experiences he never let me give up. I owe so much to him.

This book is essentially based on the archival collections of the Centre for Asia Minor Studies. I would like to express my special thanks to assistant director Stavros Anestidis for facilitating my research and to historian Dimitris Kamouzis for his valuable advice. I should like to thank the Turkish Scientific Council (TÜBITAK) for supporting me within "graduate student research program 2214-A" at Wellesley College in 2014. I wholeheartedly thank Prodromos B. Spirakos for unhesitatingly giving me precious photos of his refugee origin grandparents. I owe thanks to John Tsevas, the director of Greek Historical Evangelical Archive, for sharing with me documents and information about the Greek Protestants, and to Anastasia Papazoglou for hosting me many times in her village, Neokaisaria, and inviting me to an annual gatherings of Cappadocians in Greece. I would like to express that this book is also in memory of her lovely father Nikos Papazoglou who passed away a few years ago.

I would like to thank Eleni Patoucha for hosting me for months; for making her apartment home to me, for patiently teaching me Greek, for helping me in my translations, and more than that for being an elder sister to me. I am also grateful to the other members of my family in Greece, Andreas Baltas, Margarita Pavlou, Haris Mexa and Rudina Billa. My greatest debt is always to my parents. Without their support and patience, I would have given up long ago. They have always encouraged me with their unconditional love and neverending effort. My history-lover and story-teller father inspired me so much to become an academician. He enjoyed the topic of my book as much as I did and took me to several Cappadocian settlements to track the traces of Anatolian Orthodox together. This book is dedicated to my parents Meral and Halim Sirrı Göktürk. 


\section{Introduction}

I remember the summer I met an authentic group of Turcophone Greeks in a village called Neokaisaria (New Kayseri-Caesarea) in Ioannina, Greece. Until this encounter, I had always visualized these people as an extinct ancient community. They are not. Although spoken only by the elderly, Turkish is still alive among some second- and third-generation refugees. I distinctly recall attending a funeral that day. I was standing outside a funeral house with Maria, the daughter-in-law of the deceased woman. She was telling me how she feels when she speaks Turkish: "I speak Turkish from my heart, it is my mother tongue. I learned Greek at school, I just speak it." In the meantime, the familiar melody of lament rose from the house: Keçi bağlarında dolaniyorum, yitirdim yârimi araniyorum. ${ }^{1}$ That summer day was a magical experience for me. It was cloudy, and, in my imagination, the lament was heard from the mountains of Epirus and the Argaeus mountain greeted from far away the village of Cesareans. The guest room of the village church was decorated with photos of the ancestral land and the tiny memorial in the small square of the village was there to remind the villagers of their refugee origins. That day, I realized that my journey with these people was not yet over.

Three years after my first encounter with the Turkish speaking Greeks, I attended a festival of Cappadocians to continue my research. The festival was Gavoustima, the gathering of Cappadocians from all over Greece, which has occurred annually for almost two decades. Gavoustima is derived from the Turkish word kavuşma, meaning "coming together," and it was coined by the Cappadocian Greeks and given as a name to the festival ( $\pi \alpha v \eta \gamma v \dot{\rho} \mathrm{l})$, which each year is organized by a different local Cappadocian association and held in a different locality. Anything and everything recalling Cappadocia was there during the festival: music, dance, food, language, memories and stories from the family members about the old country. Only Cappadocia itself was absent from the picture. I tried to interview people, but our conversations were often interrupted by chit chat. I could not insist, and tried to enjoy the atmosphere. We were in Neo Agioneri, Kilkis, but it seemed to me that we were pretending to be in Misti, Niğde.

During the festival, I also noticed that the speakers addressed the audience as "the children of Cappadocian Hellenism," a title by which they distinguish themselves from the rest of Greek society in emphasis in their Cappadocian origins, 


\section{Introduction}

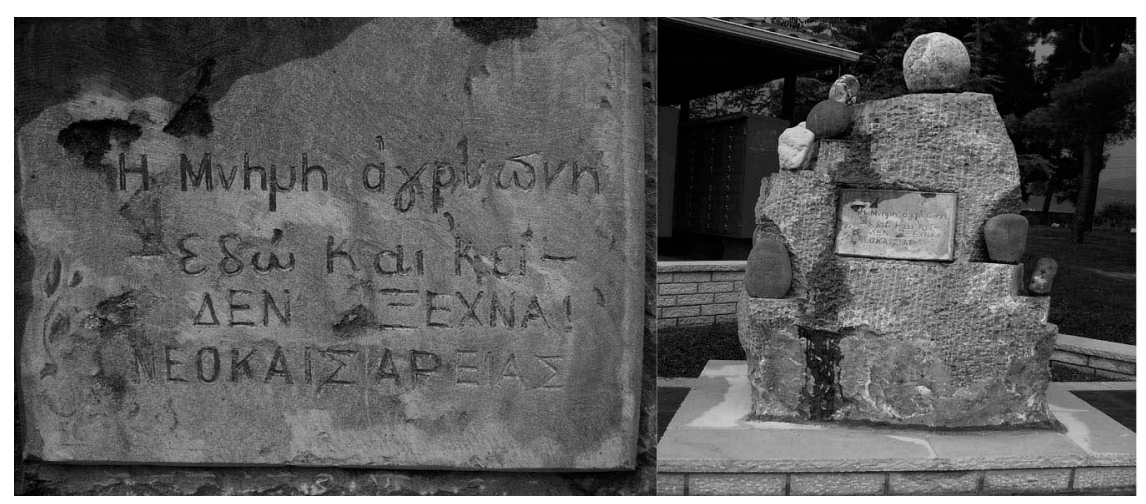

Figure 0.1 The Exchange Memorial at Neokaisaria. On its stone panel is written: "The live memory of Neokaisaria. Here and there. Never forgotten!"

Photograph: Gülen Göktürk

but without putting in doubt their "Greekness." That is to say, they celebrate their origins with feelings of nostalgia; however, nationalistic feelings are not lacking.

Still, when I think about Gavoustima, I find myself lost between amazement and incomprehension. I wonder if it is really possible to miss a place you have never physically been to. It is like a craving for food you have never tasted. I do not, of course, doubt the genuineness of their feelings of nostalgia but I do question why second and third-generation refugees still have these feelings. Confused by this question, I recall the moment when I talked to a secondgeneration Turcophone refugee in Neokaisaria in 2009. He told me about his visit to Turkey. "Do you know, my daughter? I was asked to buy land from my village of origin in Kayseri," he said, "I refused. Why settle there? My home is here." Now I realize that the attendees of Gavoustima, when celebrating their origins, were not actually pining for their lost land. This ancestral land was actually alien to them, the land of their deceased parents and grandparents. They could happily visit these lands as tourists, but they would not live there. Their feeling of nostalgia in fact has nothing to do with lost land; it is rather a fantastical romance, a way of celebrating their differences from the rest of their society. As a consequence, I believe that my study has a contemporary resonance, despite focusing on the late nineteenth and early twentieth century.

This book investigates the relationship between tolerance, cohabitation and nationalism by focusing mainly on Orthodox-Muslim and Orthodox-Protestant practices in living together in Cappadocia in the last fifty years of the Ottoman Empire (from the 1870s until the Population Exchange between Greece and Turkey, 1923), mainly due to problems in obtaining sources outside of this period. It is also an analysis of the transformation of the social identity of the Cappadocian Orthodox Christians from Christians to Greeks through various 


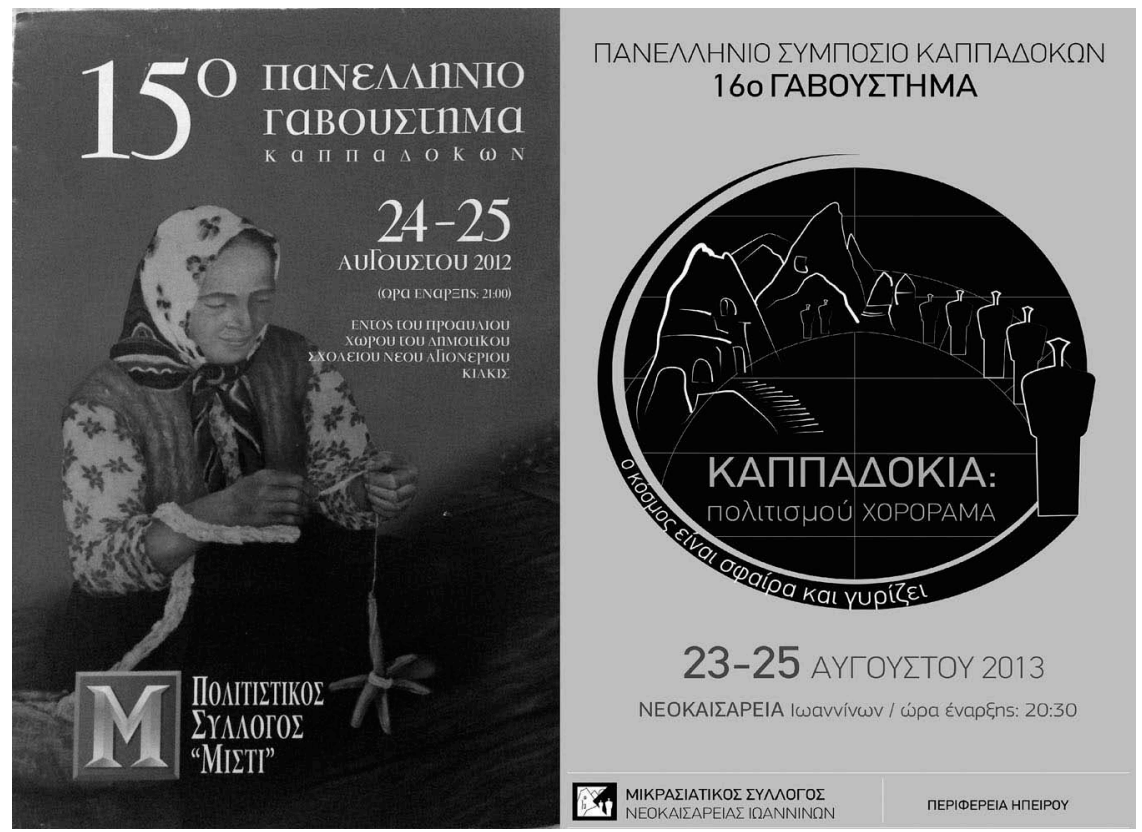

Figure 0.2 Flyers of the fifteenth and sixteenth pan-Greek Gavoustima of Cappadocians organized by the "Cultural Society of Misti" and the "Asia Minor Society of Neokaisaria, Ioannina," respectively. I owe thanks to both societies for providing me with the posters of the Gavoustima gathering they organized.

mechanisms, such as utilizing education and the press, and through all sorts of nationalist aggression during the long war (1912-1922). My greatest disappointment is that due to the absence of first-person testimonies reflecting the Turkish-Muslim perspective for cohabitation, the subject matter could only be examined through the Greek Orthodox perspective. ${ }^{2}$

The book includes many theories but essentially argues that the cohabitation practices of different communities in the pre-nationalism era provide clues to understanding how nationalism was embraced by the people. In other words, it affirms that nationalism falls into the pre-existing boundaries and dynamics of relationships between faith groups. This is not a primordialist argument that reduces national identity to Church affiliation; it investigates tolerance and competitive inter-faith living, and attributes special attention on the one hand to cultural flirting between religious communities, and on the other hand to ways of preserving boundaries and keeping the group (Self) intact in the face of the 


\section{Introduction}

potential intervention of the Other. The center of attention is the microcosms of lay people rather than the macrocosms of rulers and Church authorities.

The unique quality of this book is that it does not focus on conflict, in contrast with the general tendency of nationalism studies to focus on conflict zones, considering the fact that the nationalist ferment can easily be nourished by controversy. History demonstrates that even in areas of relative peace, nationalism found ways to establish itself, and even penetrated places where there was no visible inter-communal conflict. Cappadocia was one of those places. Despite the confessional differences between religious communities, people were not in conflict, and they enjoyed common customs, religious rituals and a shared language, spoken by most of the Christians of the region. Nevertheless, even the Cappadocian Christians eventually nationalized in the first decades of the twentieth century, a period that I call the years of discontinuity, as it represented a detachment from previous epochs due to the strict nationalist policies of the Committee of Union and Progress (the CUP), neverending wars and the eventual displacement of peoples with the Turkish-Greek Population Exchange in 1923. The elite endeavor to Hellenize the Anatolian Orthodox began earlier in the second half of the nineteenth century, but it was only successful in creating a sort of broader community consciousness, or proto-national bonds, if we follow Hobsbawm, ${ }^{3}$ especially among the people who received an education in local community schools, and among Cappadocian immigrants in big coastal towns. I will most certainly discuss the various responses to the nationalization attempts of the elites. By pinpointing the traditional relations between faith groups in a relatively peaceful ecosystem in a pre-nationalism era, the book explains this seemingly inconceivable nationalization process and, in doing this, benefits from Robert M. Hayden's concept of "antagonistic tolerance" and Peter Van der Veer's "religious nationalism,", two terms that complete one another. The former refers to competitive cohabitation, and the latter to the transformation of pre-existing religious belongingness to nationalist belongingness in some regions like India and the Balkans. In India, for example, dreams of nationhood always include religion as one of the main aspects of national identity.

This book ultimately aims to respond to current Pax-Ottomana romanticism through an investigation of a relatively peaceful region which had the potential to best exemplify the myth of "Ottoman multiculturalism," as well as through a detailed discussion of contemporary theories of accommodating plurality in order not to arbitrarily utilize concepts like tolerance, multiculturalism and justice. It is hard to deny that until recently the official historiography in Turkey was nation-state oriented; homogenization policies of the early republican era were almost never questioned, and the history of the Ottoman Empire was underrated. Nowadays the wind blows in the opposite direction; the Ottoman Empire is overly exaggerated and politicians and some scholars go even further, claiming that Ottoman plurality was "a pre-modern" or "a pre-nation-state" multiculturalism ${ }^{5}$ and that the Ottoman Empire was a land of "tolerance." 6 This approach is flawed on several points. One is that it employs the term 
"tolerance" positively and, in fact, randomly, without any reference to tolerance/ toleration debates in liberal and critical theories of justice, and implies "peaceful living together" even though these two concepts are not equal. Additionally, it remains inadequate to answer such questions as: if the Ottoman Empire was an example of "peaceful cohabitation," why was it dissolved into several nationstates? Was there really a glorious past to which we can look for solutions to solve the problems of today? And how can we label a historical occurrence with contemporary concepts like multiculturalism? This book hopes to answer these questions with an approach that questions Ottoman romanticism through an examination of Cappadocia that might have suited the romanticist arguments. As we will see, however, even then cohabitation was highly competitive, if not actually conflictual, and cannot serve as an example for today.

\section{Names and places}

From the beginning of my research I knew that I was not in a position to invent borders within contemporary Greek society. The object of my examination is a historical group of people, not contemporary Greeks of Cappadocia origin, and I am by no means trying to question anybody's "Greekness." Additionally, I am aware that some historical debates one way or another have contemporary repercussions. With that in mind, during my continuous readings about the topic, I eventually decided to drop the term Karamanl (pl. - lar), a label that is often used in historical and philological studies about the Cappadocian Orthodox. I myself also used the term in my previous studies. Karamanll was a term that was historically used by some Orthodox Christians pejoratively to address the Turcophone (and even the Grecophone) Christians from the Ottoman province of Karaman, suggestive of being vulgar peasants and savages. ${ }^{7}$

Cappadocians themselves never used the term Karamanll. Instead, they used phrases like Christians, Christians who inhabit the East, Anatolian Christians, Anatolian Orthodox and Anatolians when referring to their compatriots in their contemporary publications. ${ }^{8}$ For Richard Clogg, the term Karamanll was first used to refer to Turcophone Anatolian Christians in Greek texts of the eighteenth century, and possibly earlier. Clogg also cites a German traveler who recounted the presence of Turcophone Christians known also as "Caramanians" in Istanbul in the sixteenth century. It seems that the term Karamanll was not coined in recent centuries; ${ }^{9}$ it had in fact been in use for a long time. Some scholars have recently revived the term Karamanll and established a new category for the history and publications of Turcophone Orthodox of Anatolia, separate from the general community of the Greek Orthodox of Asia Minor. The pioneer of studies of Karamanlides and Karamanlidika is Evangelia Balta, and several other scholars adopt the term Karamanl in their studies. ${ }^{10}$ Alternatively, Stefo and Foti Benlisoy seem to hesitate to use the term Karamanl, especially in their later works, and instead refer to Anatolian Orthodox by the titles they used for themselves in their publications in the nineteenth century. ${ }^{11}$ 


\section{Introduction}

This study rejects the category of Karamanl, and studies the Orthodox of the Anatolian interior (or Cappadocia) within the general framework of the Greek Orthodox Community (i.e., Rum) of the Ottoman Empire. There are two reasons for this. First, historically, they were offended by the term Karamanll as it was a label to humiliate the Anatolian Christians. Second, speaking Turkish as a mother tongue was not peculiar to them; the Turkish speaking Orthodox did exist in other parts of Asia Minor in addition to Cappadocia. ${ }^{12}$ Further to this, despite the common belief that the Anatolian Orthodox spoke Turkish, a special Greek dialect was still present in some Orthodox settlements in Cappadocia even in the late nineteenth century. Among all eighty-two Orthodox villages of Cappadocia, Greek was spoken in the nineteenth century in twenty of them. ${ }^{13}$ Therefore, language on its own does not form a category. Last but not least, the written language called Karamanlidika was not only used in Cappadocia but also in Pontus ${ }^{14}$ and in other regions of Asia Minor, and publications in this written language could reach many places in Asia Minor and be read by members of the general Orthodox public. In short, there is no need to put the Cappadocian Orthodox in a hypothetical cage and separate them from the rest of the Greek Orthodox Community. To put it differently, although the Greek Orthodox communities of each and every region had peculiar traits that differentiated them from the broader Community, ${ }^{15}$ they were pieces of a whole. For example, the Pontic community was different from the Ionian community. Similarly, the Cappadocian community had distinguishing characteristics due to its peculiar geography, neighborly relations, socio-economic conditions and history. However, they all belonged to the Greek Orthodox Community. We can certainly distinguish and categorize them according to their place of origin and study a particular local community, but I disapprove of any approach that has the tendency to invent new "ethnic" groups within an "ethnic" group. ${ }^{16}$

As a general rule, the Orthodox communities in city centers were Turcophone. Greek was preserved predominantly in the villages. The more conservative the people, the more they tended to retain their linguistic identity. Since they dealt with economic activities in public places like markets and bazaars, men spoke Turkish, whereas women, if they did not live in a mixed village, continued to preserve and speak Greek and have a limited knowledge of Turkish. In the nineteenth century, however, this situation changed. As a result of male immigration to big cities, in poorer villages women started to work in Turkish fields and houses. Due to the fall in male population and female exposure to the Turkish language, the Cappadocian Orthodox faced a larger loss of linguistic identity than in previous centuries. Toward the end of the century, even in the few remaining Greek-speaking villages, Greek was replaced with Turkish. ${ }^{17}$

In light of the above-stated arguments, throughout the study I interchangeably use the terms Cappadocian Orthodox, Cappadocian Christians, Cappadocians, Anatolian Orthodox, Greek Orthodox of Anatolia or simply Orthodox and Anatolian Christians. Since their nationalization was in process and incomplete during this 
time period, I hesitate to use the term Greek since it denotes ethnicity and nationality. As for the other side, I either employ the term Muslim or Turk; in the prenationalism era both meant adherence to Islam and the concept of Turk did not have any ethnic connotations and was often used by non-Muslims for their Sunnite neighbors. Interestingly, the Anatolian Orthodox referred to the Alawite communities as Turkmens (Turcomans). ${ }^{18}$ It seems that the concepts of Turk and Turkmen had solely religious meanings for them. Concerning the Protestant converts of Greek Orthodox origin, I have introduced the concept of Greek Protestants. Here, Greek refers to their previous membership of the Greek Orthodox congregation.

Another important point to clarify is the geographical term Cappadocia. As I mentioned, those Orthodox Christians also called Karamanll were the inhabitants of the Karaman Eyalet (a subdivision of the Ottoman Empire), and they were named after their place of origin (the suffix $-l l$ is used to denote place of origin in Turkish). Until the advent of the Provincial Redistricting Act (Teşkil-i Vilayet Nizamnamesi) in 1864, the Karaman Eyalet included seven sanjaks (provincial districts): Konya, Niğde, Akşehir, Beyşehir, Aksaray, Kayseri and Kirşehir, in line with contemporary Turkish administrative structure. The territories of the Karaman Eyalet were at the same time the land on which the Karamanid Dynasty had reigned (1250-1487). With this new Act, the Karaman Eyalet turned into the province of Konya (Konya Vilayeti). The province of Konya now consisted of the sanjaks of Konya, Isparta, Burdur, Antalya and Niğde. Kayseri and Kurşehir were now parts of the province of Ankara, along with the sanjaks of Yozgat, Çorum and Ankara. In short, the Anatolian Orthodox were the settlers of a union of Konya and Ankara provinces. The only missing area is the sanjak of Adana in considering the Orthodox settlements.

Anagnostopoulou maps out the regions where there was a high concentration of Greek Orthodox communities in interior Asia Minor, and employs Byzantine province names. There were two areas with a significant proportion of Greek Orthodox communities: Cappadocia and Lycaonia. Cappadocia included the sanjak of Adana from Cilicia and Kırşehir from Galatia. For her, Cappadocia and Lycaonia together were Greater Cappadocia. Balta, on the other hand, defines Greater Cappadocia in accordance with the settlements of Turcophone communities. In her explanation, it lay to the north as far as Ankara, Yozgat and Hüdavendigar, to the South Antalya and Adana, to the East Kayseri and Sivas, and to the West as far as the borders of Aydin province. ${ }^{19}$

The Cappadocian Orthodox were very few in number compared to their Muslim neighbors, and their settlements were very scattered. For this reason, we cannot possibly limit the borders of Cappadocia by the physical particularities of the region. Due to dispersion, the ecclesiastical division did not overlap with the Ottoman administrative structure. For example, a metropolis could contain two or three different provinces; conversely, there could sometimes be two or three metropolises in one Ottoman province. ${ }^{20}$ For this reason, historians' descriptions of Cappadocia might seem confusing, because some are inclined to define it in accordance with the ecclesiastical division, and some with the Ottoman administrative division. 


\section{Introduction}

This book is not particularly concerned with the Turcophone Orthodox of the whole Asia Minor but with the Orthodox of Cappadocia and draws the boundaries of Cappadocia as a union of the provinces of Ankara and Konya plus the sanjak of Adana in line with the 1864 Administrative Act. It focuses predominantly on the Greek Orthodox settlements in Kayseri, Niğde, Aksaray and Nevşehir. For the purpose of this book, in addition to the interviews with the refugees from these areas, the narrations of refugees from Keskin (Kırşehir), Gürümce (Adana) and Silli (Konya) are also utilized. Throughout the book, Cappadocia and interior Anatolia are used interchangeably.

By the time of the Turkish-Greek Exchange of Populations in 1923, the Orthodox communities living around Kayseri were Turcophone. The region was famous among the Greek Orthodox Community as the land of St. Basil the Great (fourth century AD), and was an old center of Christianity. The Metropolitan Bishop of Kayseri lived in Zincidere, thirteen kilometers north of Kayseri, a center of education and religion for the Orthodox since the Monastery of John the Forerunner, and the only Seminary located in Cappadocia. Unlike Kayseri, the Greek Orthodox communities of Niğde were mixed in terms of their mother tongue. Those who lived in the city center were Turcophone, but there were both Grecophone and Turcophone villages, as well as villages where people

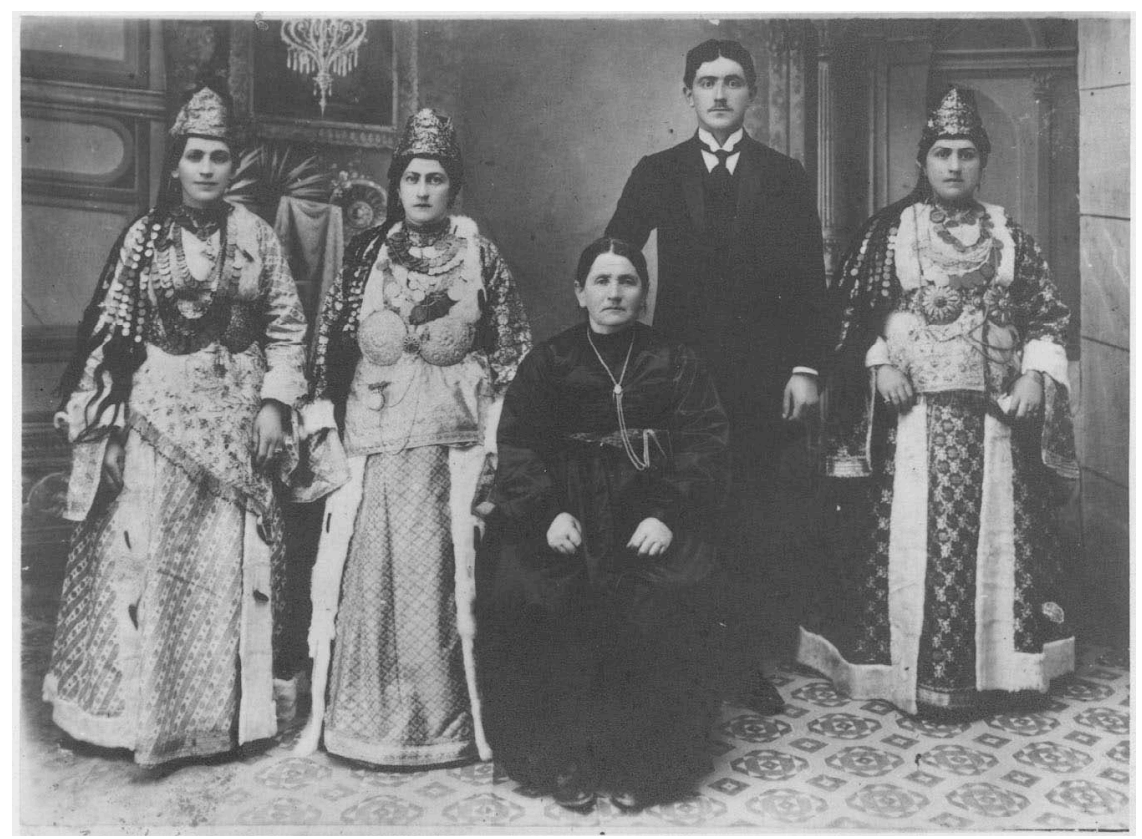

Figure 0.3 The Hasatani family in their local costumes, Sille, Konya

Source: Prodromos B. Spyrakos. Permission granted by the family. 


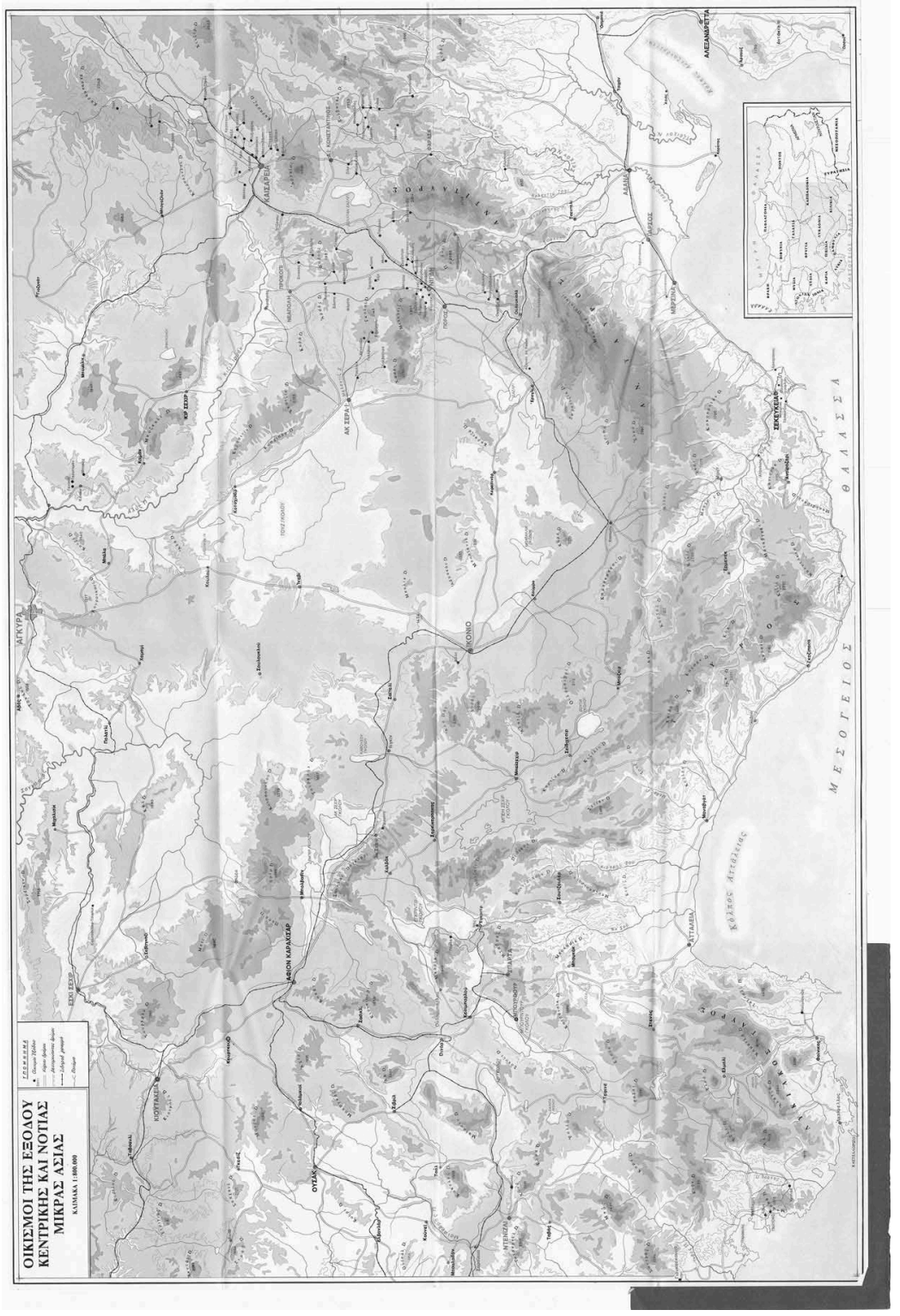

Figure 0.4 Map of Central and Southern Anatolia.

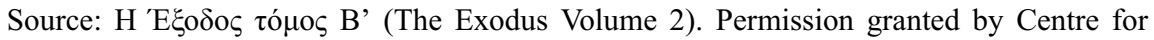
Asia Minor Studies. 


\section{Introduction}

spoke both languages. Interestingly, in Grecophone villages, people are reported to have sung their songs in Turkish. The Metropolitan Bishop of Konya lived in Niğde. As for Nevşehir, there were both Turcophone and Grecophone settlements. For example, the community of Sinasos was Grecophone, whereas the community of Malokopi was Turcophone. Lastly, the number of Greek Orthodox people in Aksaray was low compared to the other centers of Cappadocia. The most important Orthodox settlement was Gelveri with its four thousand Orthodox inhabitants. ${ }^{21}$

\section{Sources and methodology}

Early studies of the Cappadocian Orthodox have been very crucial for this book. However, in order to make a solid contribution to the existing literature I chose to dwell on the faces of the crowd and, therefore, devoted an enormous amount of my research time to examining the Oral Tradition Archives (A $\rho$ cío

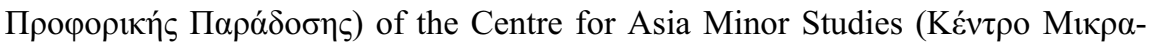

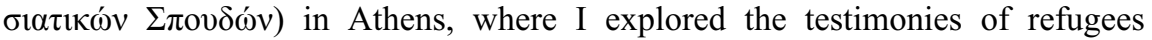
from Central Anatolia and also utilized the library collection. Additionally, I made use of the rare books about individual Evangelicals and the missionary

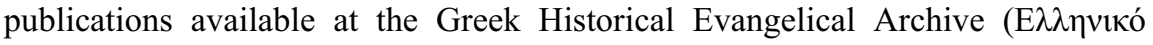

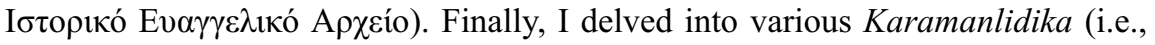
Turkish in Greek letters) publications of the time, including almanacs, regulations of brotherhood organizations, newspapers, periodicals like Anatoli, Terakki and the missionary newspaper Angeliaforos.

The Oral Tradition Archives at the CAMS contains interviews conducted with over five thousand refugees from the early 1930s to the early 1970s. The project was initiated by a Greek aristocrat Melpo Logotheti Merlie (1890-1979). My first impressions of the oral tradition accounts were that I was in serious trouble, as the refugee testimonies were purely nostalgic; they were conducted years after the events and with people who had already passed away, so I had no opportunity to clarify any point I did not understand. Moreover, I also had no idea of the questions asked by the researchers of the CAMS to the refugees; I could only read the answers and then attempt to guess the questions as they related to topics like schools, migration, the Exchange of Populations, TurkishGreek relations, nearby villages, etc. I read the accounts in Greek even though most of the refugees were documented as Turkophone, and I wasn't completely sure about the accuracy of the translations. For example, I had no idea what word would have been used by the interviewees in Turkish for the word Greek

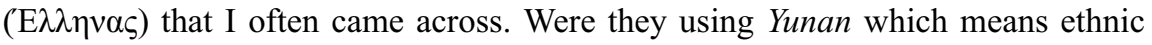
Greek or Rum which means Greek Orthodox Christian? With these questions in mind I read the writings of two scholars, namely Papailias and Kapoli who critically, even fiercely, evaluated the Oral Tradition Archives of the CAMS. ${ }^{22}$ Their works helped me refine my thoughts about the Oral Tradition Archives and make my analysis carefully. 
First of all, Papailias warns researchers about the founder of the Oral Tradition Archives Merlie's interpretation of Turkish-Greek co-existence, underlined as it is with a desire for a more tolerant future. For Papailias, Merlie encouraged her researchers to find signs of harmonious interethnic relations and not to highlight any Turkish violence against Greeks. What could be the reason for this stance? Was she a philanthropist, a humanist or just a liberal? It is a difficult question to answer, but it seems that it was mainly a romantic attitude, probably because she was fascinated by her encounter with the Turks in Cappadocia to where she had traveled on a center-sponsored journey, something she herself stated in her correspondence. In line with Merlie's interest, Cappadocia became the Centre's focal point and consequently thirty-four percent of the interviewees selected were Cappadocians. As mentioned, Cappadocia and/or Central Anatolia was perhaps the most peaceful region in the Ottoman Empire so an "Ottoman tolerance" or "peaceful cohabitation" discourse could easily be generated with reference to Cappadocia. According to Papailias, Merlie was well aware that Cappadocia would suit her objective of portraying harmonious cohabitation in the Ottoman Asia Minor. Papailias's warning drove me to be more cautious in evaluating testimonies heavily nostalgic for lost homelands ( $\chi \alpha \mu \varepsilon$ ćve $\pi \alpha \tau \rho i ́ \delta \varepsilon \varsigma)$ and for the "good Turkish neighbor."

Second, for Papailias and Kapoli, when the CAMS researchers knocked on the doors of refugees to gather information about their hometowns in Asia Minor, the stories that they were expected to tell were of their distant past and few of them were eager to narrate it. For many, it was "a lament over ruins." 23 They had relatively positive feelings about their life in Asia Minor, especially following the Second World War, Civil War and all the hardships of refugee life after their expulsion and the Exchange. Papailias's statements match my observations. I have not come across any testimony that argues that life in Greece was better than life in Asia Minor. Therefore, the refugees were recreating a world of peace in a distant past under the sway of the discomfort they felt in the conditions existing at the time they were interviewed, and looking back was a source of pleasure for them.

The interviews invented Asia Minor but not the land the refugees lived on. The source of their imagination was the difference between present and past. Their nostalgia harbored dichotomies like past and present, existing and non-existing, here and there, remembering and forgetting, us and them etc. ${ }^{24}$ Similarly in the Oral Tradition Archives, there were good and bad Turk, Asia Minor and Greece, present

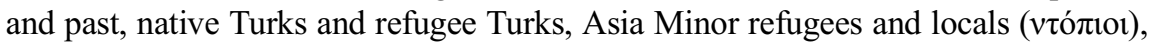
Christianity and Islam, and the periods before and after the Young Turk Revolution of 1908. Almost every detail or experience was narrated in comparison to something else. The frustration of their present conditions was reflected as a longing for the past. Remembering the bad was always accompanied by remembering the good. Dichotomies are important in weighing refugee perceptions and making conclusions. For example, a distinction between good and bad Turks in a refugee narrative implies that Turk is the Other, an external actor, if not an enemy. 


\section{Introduction}

Many historians find memory as a source of history writing less credible since it is open to distortion more than written sources. Especially with oral histories, which deal with the distant past, there is the possibility of distortions influenced by changes in values and norms that might unconsciously change perceptions. ${ }^{25}$ So, when CAMS researchers interviewed people about their life in Asia Minor, a lot of water had flowed under the bridge and memories were already reshaped by the recent past and the present. Another difficulty was raised by eighty-two-year-old Alexandros Yagtzoglou to a CAMS researcher in 1957 :

You should have come ten years before. In those years everything was fresher in my mind. Now it is late. Most of our people died and so did the brains of the remaining people, we are not able to tell anything. ${ }^{26}$

Yagtzoglou was right; their experiences in Asia Minor were now filtered by the years between then and now and now as they were elderly they could barely remember the details. All these are fair concerns for oral history in general and the Oral Tradition Archives in particular. A student of oral history should be clear about what (s)he looks for in oral history as a material for any academic endeavor because its credibility lies in the symbolism, imagination and meaning they include, if not in its adherence to facts. ${ }^{27}$

Memories are repetitions and since they are reproduced in very different systems of notions and at different periods of our lives, they lose the form and appearance they originally had. My personal stance is that memory is a reflection of societal norms and past experiences; so it is collective, but this does not mean that individuals are totally passive in this process. Memory is a social as well as an individual process, and the more significant a name or face is the more likely it is to be remembered, so memory depends on individual comprehension as well as upon individual interest. This is along the lines of what I observed in the oral tradition accounts. The presence of good interpersonal relations with a member of the Other positively affected the general perception of Turks in the eyes of refugees. Despite the hardships originating from nationalist CUP policies in the last two decades of the Empire, a relentless period that was lived through by the interviewed refugees, and despite the antiTurk propaganda they faced after their expulsion, a refugee could say, for instance, "nowadays they say a lot about Turks; we never met such Turks. They must have been other people. They were good and respectful to women. I wish everybody would be like Turks." 28 Or, conversely, a refugee could label Turks pejoratively because of bad inter-personal encounters and antagonistic intercommunal relations in his/her locality, and so easily adopt "the bad Turk" image created by Greek nationalist propaganda. As in the lines of a refugee testimony: "When they saw us coming from a revelry, Turks would be jealous of us. They could initiate a fight. You could not say 'long live Greece!",29

As previously claimed, the testimonies at the CAMS were overly nostalgic, and I initially regarded this as a pitfall for my research. Many scholars see 
nostalgia as "sentimental kitsch." ${ }^{30}$ Nostalgia might distort past events, but it tells us about their meaning in the present time. It might also create a problem of anachronism since it informs about the past using feelings of the present. As an example, in the oral testimonies I looked at, refugees made distinctions about the years before and after the Young Turk Revolution (1908), where the Hamidian years were seen as relatively good in comparison with the hardships they went through afterward. If not approached carefully, the Hamidian years could be evaluated as the "good old days." However, it was also a period of censorship, Armenian massacres, forced conversions and Islamist policies, and most likely for Christians it was worse than the previous Tanzimat period. Since the testimonies in the Oral History Archives do not tell us anything about the years before the reign of Abdülhamit II, it would be easy (though incorrect) to conclude that the Hamidian period was a belle époque. In order to avoid such a conclusion, a researcher has to have a sense of history developed through supporting readings and comparative analysis of different areas of diversity.

Selectiveness is also an issue in research supported by and reliant on oral history and memory. It is often claimed that there are good memories and bad memories and memory mostly works in favor of good memories. However, the notion of good and bad differs from person to person. Remembering good or bad, I believe, is closely related to the respective intentions of the interviewee and the researcher. If a researcher conducts a study about the massacre of a particular group of people, for example, his/her questions would more often remind the interviewee of bad memories, and if an interviewee has bad feelings toward the people (s)he is talking about (s)he might stress the bad memories. Therefore, if forgetting and selectiveness are pitfalls, my suggestion to overcome these issues is not to focus on the interesting and rare stories of individual interviewees, but instead on the common things in different interviewees' narratives. After all, says Caunce, it is the ordinary events that shape our lives and for this reason a historian should be interested in typical events, not extraordinary ones. $^{31}$ To put it a different way, the collection and analysis of specific details of narrowly limited events, developments, or phenomena result in loss of perspective and neglect of context. ${ }^{32}$ My study covers many interviewees, both urban and rural, from different settlements of Cappadocia, and I focus on the common points in their narratives because shared social frameworks of individual recollections constitute the basis of this book. This way I prevent myself from falling for the romantic vision that prevails in studies about Ottoman plurality. As for my book, I will try to complete the picture drawn by the Oral Tradition Archives through historical imagination in addition to two publications of the Anatolian Orthodox Anatoli and Terakki, as well as the missionary publications Angeliaforos and The Missionary Herald.

Except for The Missionary Herald all three of the above-mentioned publications were in Karamanlidika and emerged in the second half of the nineteenth century. "The teacher of Anatolia," Evangelinos Misailidis, started publishing Anatoli in Izmir in 1843 and after a break he continued to publish it in Istanbul starting in 1851. The newspaper survived until 1912 or 1922 . Scholars do not agree upon an 
exact date. Anatoli was followed by Nea Anatoli which survived between the years 1912-1923. ${ }^{33}$ Anatoli was one of the major and most circulated newspapers of the time among the Orthodox Community and contributed massively to the development of Turkish in the Greek alphabet. In time, the expression of Turkish sounds with Greek letters took a conventional form in the newspaper and became a source of reference for Karamanlidika for the Anatolian Orthodox, so that after a while the newspaper started to criticize those who made orthographical mistakes when writing Turkish in the Greek alphabet. Interestingly, the Turkish language used in the paper became plainer over time. It was first due to reader complaints since many of its readers were not familiar with Ottoman Turkish and could only speak simple Turkish. Second, it was a result of the general pattern of elimination of Arabic and Persian words and phrases in the language at the time. The readers of Anatoli were mainly the Turcophone Orthodox from Istanbul and interior Anatolia. For the purposes of this book, I have benefited particularly from the issues of Anatoli published in the last decade of the nineteenth century (1891-1897); however, I also examined a few issues from the period 1851-1854 to see how Anatoli's purpose of emergence was portrayed during its initial years, and to cite some relevant examples. A whole book could easily be written just about Anatoli, but I never intended to dwell specifically on Anatoli, only to benefit from it.

The short-lived Terakki (progress) was another publication I perused and it was published in the heart of Cappadocia in Nevşehir in 1888. As can be understood from the title, it was aimed at the progress of Anatolia, as did Anatoli, and published articles about science, medicine, general knowledge, religion, history (including Ottoman history), morality, human development and concerns for the future of Anatolia.

Unlike these two, the missionary newspaper Angeliaforos was first published in 1872 by the American Board of Commissioners for Foreign Missions (ABCFM) in Istanbul in Karamanlidika. There were also Armenian and Armeno-Turkish versions of the paper, both of which were called Avedaper and emerged in 1855 and 1860, respectively. Angeliaforos means "the bringer of good news" or simply "the messenger." The paper is composed of three main departments, religion, education, and family, and concludes with a summary of both domestic and foreign news. For this book, I was able to study the issues of Angeliaforos published between 1889-1890 and 1903-1904. The Missionary Herald reported that, by 1903, the number of subscribers of the three versions of the paper was almost exactly two thousand five hundred (Barnum, 1903). Although the other two versions were bought by Armenians, this means that Angeliaforos was circulated almost double that of Anatoli, whose subscribers were five hundred by 1890 and three hundred by $1895 .^{34}$ The missionary newspapers Avedaper and Angeliaforos had the same content and they not only targeted the newly converted but also the large class of people who sent their sons and daughters to missionary schools and the people who never attended their services.

Another written source I have used for this book is The Missionary Herald, the magazine of ABCFM published in Boston. It reported from foreign missions in China, India, the Near East, Africa and Indigenous 
populations of the Americas, among others. This magazine covered a wide range of topics, including local customs, cultures, geography and history; success stories in topics regarding missionary work; and education and health missions or the reasons for their failure. For this book, I looked at issues it raised from the 1870 s to 1922 .

\section{Themes}

The book is ultimately a response to the Pax-Ottomana romanticism especially prevalent in current political discourse. This anachronistic perspective portrays Ottoman plurality as a pre-modern equivalent of multiculturalism, and seeks to cure current minority issues and identity claims of the country by referring to the "Ottoman tolerance" myth. I call it a myth since the term "tolerance" is used randomly without any reference to theoretical discussions about it. Similarly, multiculturalism is arbitrarily employed disregarding its fallacies.

I first analyze the term tolerance, and discuss the possibility of generating a new perspective of the term. I then continue with the Ottoman way of dealing with diversity, and open a debate about some free-floating terms like millet system and religious tolerance. I determine Ottoman tolerance to be negative, religious, and pragmatist (in times of crisis it could also be intolerant), and indifferent in nature.

I explore Ottoman tolerance at a societal level and consider the practices of living together in Cappadocia, because it is my contention that no other region of the Empire would be better suited than Cappadocia to buttress the romanticist thesis of "peaceful cohabitation." Nevertheless, a close-up study of Cappadocia illustrates that, even there, religion - the primary vehicle of border maintenance - sets the rules of rivalry between communities, and it was in fact this rivalry that provided a suitable setting for nationalism. There is a general misinterpretation that at a societal level tolerance is equal to peaceful living together. In an ecosystem where tolerance prevails, we often do not notice conflict until times of crisis, but little or no conflict does not necessarily equate to peaceful cohabitation. Although Cappadocia was one of the least conflictual regions of the Ottoman Empire, practices of living together were still highly competitive, rather than peaceful, indicating antagonistic tolerance at an inter-communal level. In this ecosystem of Cappadocia (and elsewhere in the Empire), the borders between "us" (Self) and "them" (Other) were determined by religion, and the Anatolian Orthodox did not want to lose members to either the dominant religion of Islam, or any other Christian denomination like Protestantism. The Orthodox Community was already small and was shrinking due to emigration in the nineteenth century, so border maintenance was particularly important. However, although Muslims were both numerically and culturally dominant in Cappadocia, non-Muslims did not necessarily close themselves off from them. Despite the prevailing competition at the inter-communal level, there was also proximity and intimacy at an inter-personal level. 


\section{Introduction}

Like the non-Muslims of other regions of the Empire, the Cappadocian Orthodox entered a process of nationalization in the late nineteenth century. I analyze their Hellenization and show the relation between pre-existing cohabitation practices and nationalism. Three main factors helped in the creation of broader community consciousness and proto-national bonds among the Cappadocian Orthodox: first, the increasing male emigration to foreign lands due to economic opportunities that emerged with the arrival of European capital in major port cities of the Empire, and construction of railroad networks that facilitated the connection between homeland and foreign lands; second, the foundation of the Greek Kingdom and its irredentist policies over the Asia Minor Orthodox, initially through cultural means like education and propagation through the syllogoi (societies) and press; and third, the importance attributed to education by the Church as a response to missionaries and as an outcome of Ottoman reforms that facilitated the entrance of lay people to administrative bodies of millet. Consequently, the Anatolian Orthodox became aware of their kinship ties with the Orthodox of other regions for the first time, and began to realize the presence of a broader Community that included other communities as well as their own local community (koinotis).

Until the nationalist aggressiveness of CUP policies particularly targeted foreign investments and non-Muslims, Orthodox folk were still relatively indifferent to nationalism, and regarded it as an attack on their religious identity. On the other side of the coin, among the intellectual circles of the Orthodox there were Greek nationalists who received their educations at the important institutions of Athens, Istanbul and elsewhere, there were Ottomanists who were also educated at major schools but believed in the integrity of the Empire, and there were proto-nationalists who received education from local community schools and were taught by nationalist teachers. As for the remaining people, seeds of Greek nationalism could only bear fruit after the Young Turk Revolution, and only then did nationalism begin to forge the social identity of the great amount of people. During this process, the germ of nationalism settled on the preexisting Self-Other dichotomy that had long been based on religious differences. In the end, both Turkish and Greek nationalisms were religious nationalisms that chose their prospective members according to their religion. As a general rule, the relatively peaceful atmosphere created by antagonistic tolerance dissolved in times of crisis, and mostly ended in internecine wars and massacre, which is what happened in the Balkans, for example. In Cappadocia, however, even during times of crisis, we don't see big clashes or conflicts but instead the rise of communal borders and an adoption of national identity of a deeper intensity than previously. Accordingly, I argue that the nationalization of the Cappadocian Orthodox could only be completed after their expulsion and their direct exposure to the ideological apparatus of the Greek state.

Returning to the tolerance debate, there were occasions when the Anatolian Orthodox were in the position of tolerators. In their relations with the Greek Protestants, who had changed their denomination under missionary influence, the Orthodox were either intolerant or, due to kinship with the converts, they 
remained indifferent and negatively tolerant. I analyze the curious case of the Greek Protestants who remained invisible in the historiography of the nonMuslims of the Ottoman Empire, and portray their lives especially in their relations with the Orthodox with whom they had blood ties.

\section{Notes}

1 "I am moving around Keçi (Gesi) vineyards; I have lost my beloved and I am looking for him". A well-known folksong in Turkey and, apparently, in Greece. The song was sung by Nikos Papazoglou in September 2009 in Neokaisaria, Ioannina, Greece. His parents were refugees from Kayseri and his mother tongue was Turkish.

2 Early Turkish novels can give us some perspective on the Turkish point of view towards the Greek or Orthodox element in the Ottoman Empire. However, having been written in the strife-filled first two decades of the 1900s and mostly by intellectuals who had been deeply affected by the political circumstances, I do not think that these novels portray a lay point of view. For Cappadocia in particular, it seems that the only novel that was written about the Orthodox of the region was Mahmut Yesari's first novel "Bir Namus Meselesi" (A Matter of Honor) which was serialized in the magazine Kelebek in 1923. This was a novel about Orthodox Christians from Kayseri who continued their lives in Istanbul. For more information about this novel see, S. T. Anestidis, Yunan ve Türk Edebiyatında Erken Karamanlı Tiplemeleri. In short, due to a lack of sources the Turkish point of view about their Christian compatriots is unfortunately absent from this study.

3 See E. Hobsbawm, Nations and Nationalism since 1780: Programme, Myth, Reality.

4 See R. M. Hayden, (Ed.), Antagonistic Tolerance: Competitive Sharing of Religious Sites and Spaces; P. Van der Veer, Religious Nationalism.

5 Aslı Iğsız devotes a title for the discussion of Neo-Ottomanism in her new book and labels it as an anachronistic vision of history. According to Iğsız, the Neo-Ottomanism talk is all about marketing Turkey as a brand. See A. Iğsız, Humanism in Ruins, pp. 199-203. See also A. Iğsız, Documenting the Past and Publicizing Personal Stories: Sensescapes and the 1923 Greco-Turkish Population Exchange in Contemporary Turkey.

6 For a typical example of this scholarship, see Y. Yıldırım \& K. H. Karpat, (Eds.), Osmanlı Hoşgörüsü. In the introduction to the book, the authors explain that their purpose for studying Ottoman tolerance is to present this historical model as an inspiration to find ways to develop peaceful co-habitation for the peoples of the Middle East. For another example, see J. McCarthy, The Ottoman Peoples and the End of Empire, pp. 2-9.

7 See F. Benlisoy \& S. Benlisoy, Türkdilli Anadolu Ortodokslarında Kimlik Algısı.

8 See E. Balta, Gerçi Rum isek de Rumca Bilmez Türkçe Söyleriz: The Adventure of an Identity in the Triptych: Vatan, Religion and Language; R. Clogg, Some Karamanlidika Inscriptions from the Monastery of the Zoodokhos Pigi, Balıklı, Istanbul; F. Benlisoy \& S. Benlisoy, Türkdilli Anadolu Ortodokslarında Kimlik Algısı.

9 R. Clogg, Some Karamanlidika Inscriptions from the Monastery of the Zoodokhos Pigi, Balıklı, Istanbul, p. 56.

10 In addition to Evangelia Balta, Richard Clogg, Elif Renk Özdemir, Merih Erol, Şehnaz Şişmanoğlu Şimşek and Robert Anhegger preferred to use various versions of the term Karamanl, like Karamanlides (plural Greek form), Karamanlis (an anglicized form), and Karamanlılar (plural Turkish form). See E. Balta, Gerçi Rum isek de Rumca Bilmez Türkçe Söyleriz: The Adventure of Identity in the Triptych: Vatan, Religion and Language; R. Clogg, A Millet Within a Millet: Karamanlides; E. R. Özdemir, Borders of Belonging in the "Exchanged Generations of Karamanlis"; M. Erol, Cultural Manifestations of a Symbiosis: Karamanlidika Epitaphs of the Nineteenth Century; Ş. Ş. 
Şimşek, The Anatoli Newspaper and the Heyday of the Karamanlı Press; R. Anhegger, Evangelinos Misailidis ve Türkçe Konuşan Dindaşları.

11 For a critical article about the use of the term Karamanli, see F. Benlisoy \& S. Benlisoy, Türkdilli Anadolu Ortodokslarında Kimlik Algısı.

12 According to the Greek census of 1928, there were 103,642 Turcophone Christians in Greece. 50,000 of them were from Cappadocia and the others were from Pontus

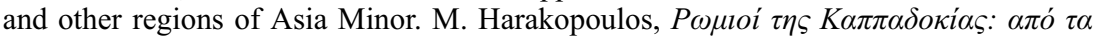

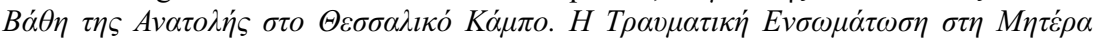
$\Pi \alpha \tau \rho i \delta \alpha$, p. 34.

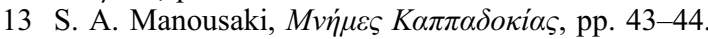

14 In this book the names "Pontus" and "Black Sea Region" are used interchangeably.

15 When I write Community with a capital "C", I mean the Greek Orthodox Community as a whole rather than a local community.

16 It does not seem proper to call the Orthodox Community in the nineteenth century an ethnic group, since they were simply a faith group, most of whose members had primitive to no ethnic consciousness that time. Here, I use the term "ethnic" from a contemporary perspective.

17 R. Dawkins, Modern Greek in Asia Minor: a Study of the Dialects of Silli, Cappadocia and Pharasa with Grammer, Texts, Translations and Glossary.

18 CAMS, Cappadocia, Gelveri, Symeon Kosmidis.

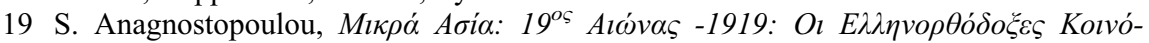

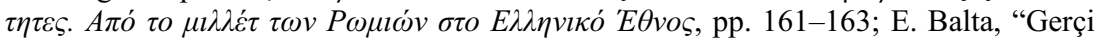
Rum isek de Rumca Bilmez Türkçe söyleriz" The Adventure of an Identity in the Triptych: Vatan, Religion and Language, p. 26.

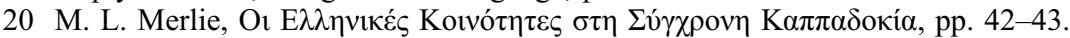

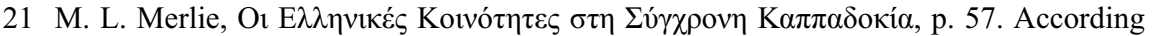
to Xenophanes, a periodical of the "Society of Anatolians, The East," the number of Orthodox in Gelveri was three thousand five hundred by 1905. For statistics about the inhabitants of Cappadocian settlements, and for information about Orthodox schools,

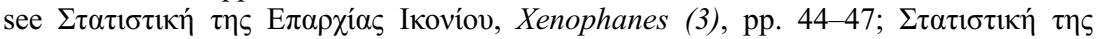

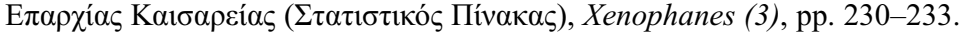

22 See P. Papailias, Genres of Recollection: Archival Poetics and Modern Greece Anthropology, History, and the Critical Imagination; E. Kapoli, Archive of Oral Tradition of the Centre for Asia Minor Studies: Its Formation and its Contribution to Research.

23 E. Kapoli, Archive of Oral Tradition of the Centre for Asia Minor Studies: Its Formation and its Contribution to Research, p. 19.

24 M. N. Layoun, Wedded to the Land? Gender, Boundaries and Nationalism in Crisis, p. 38 .

25 P. Thompson, The Voice of the Past, p. 128.

26 CAMS, Cappadocia, Niğde.

27 A. Portelli, What Makes Oral History Different? p. 69.

28 CAMS, Cappadocia, Endürlük (Androniki), Evanthia Ikenderoglou.

29 CAMS, Cappadocia, Misti, Mak. Damianoglou

30 D. Walder, Post-colonial Nostalgia: Writing, Representation, Memory, p. 4.

31 S. Caunce, Sözlü Tarih ve Yerel Tarihçi, p. 26

32 T. Philipp, Bilād Al-šām in the Modern Period: Integration into the Ottoman Empire and New Relations with Europe, p. 401.

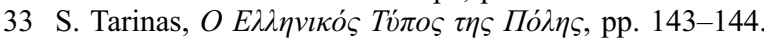

34 N. T. Soullidis. (11 December 1890). Hemșerilerimize. Anatoli, 4271; N. T. Soullidis. (5 December 1895). Anatoli Gazetesi Ser Muharriri Rifatli Ioannis Kalfaoglou Efendi'ye. Anatoli, 5173. 


\section{Notes}

\section{Introuction}

1 "I am moving around Keçi (Gesi) vineyards; I have lost my beloved and I am looking for him". A well-known folksong in Turkey and, apparently, in Greece. The song was sung by Nikos Papazoglou in September 2009 in Neokaisaria, Ioannina, Greece. His parents were refugees from Kayseri and his mother tongue was Turkish.

2 Early Turkish novels can give us some perspective on the Turkish point of view towards the Greek or Orthodox element in the Ottoman Empire. However, having been written in the strife-filled first two decades of the 1900s and mostly by intellectuals who had been deeply affected by the political circumstances, I do not think that these novels portray a lay point of view. For Cappadocia in particular, it seems that the only novel that was written about the Orthodox of the region was Mahmut Yesari's first novel "Bir Namus Meselesi" (A Matter of Honor) which was serialized in the magazine Kelebek in 1923. This was a novel about Orthodox Christians from Kayseri who continued their lives in Istanbul. For more information about this novel see, S. T. Anestidis, Yunan ve Türk Edebiyatında Erken Karamanlı Tiplemeleri. In short, due to a lack of sources the Turkish point of view about their Christian compatriots is unfortunately absent from this study.

3 See E. Hobsbawm, Nations and Nationalism since 1780: Programme, Myth, Reality.

4 See R. M. Hayden, (Ed.), Antagonistic Tolerance: Competitive Sharing of Religious Sites and Spaces; P. Van der Veer, Religious Nationalism.

5 Aslı Iğsız devotes a title for the discussion of Neo-Ottomanism in her new book and labels it as an anachronistic vision of history. According to Iğsız, the Neo-Ottomanism talk is all about marketing Turkey as a brand. See A. Iğsız, Humanism in Ruins, pp. 199-203. See also A. Iğsiz, Documenting the Past and Publicizing Personal Stories: Sensescapes and the 1923 Greco-Turkish Population Exchange in Contemporary Turkey.

6 For a typical example of this scholarship, see Y. Yıldırım \& K. H. Karpat, (Eds.), Osmanlı Hoşgörüsü. In the introduction to the book, the authors 
explain that their purpose for studying Ottoman tolerance is to present this historical model as an inspiration to find ways to develop peaceful cohabitation for the peoples of the Middle East. For another example, see J. McCarthy, The Ottoman Peoples and the End of Empire, pp. 2-9.

7 See F. Benlisoy \& S. Benlisoy, Türkdilli Anadolu Ortodokslarında Kimlik Algis1.

8 See E. Balta, Gerçi Rum isek de Rumca Bilmez Türkçe Söyleriz: The Adventure of an Identity in the Triptych: Vatan, Religion and Language; R. Clogg, Some Karamanlidika Inscriptions from the Monastery of the Zoodokhos Pigi, Balıklı, Istanbul; F. Benlisoy \& S. Benlisoy, Türkdilli Anadolu Ortodokslarında Kimlik Algısı.

9 R. Clogg, Some Karamanlidika Inscriptions from the Monastery of the Zoodokhos Pigi, Balıklı, Istanbul, p. 56.

10 In addition to Evangelia Balta, Richard Clogg, Elif Renk Özdemir, Merih Erol, Şehnaz Şişmanoğlu Şimşek and Robert Anhegger preferred to use various versions of the term Karamanl, like Karamanlides (plural Greek form), Karamanlis (an anglicized form), and Karamanlılar (plural Turkish form). See E. Balta, Gerçi Rum isek de Rumca Bilmez Türkçe Söyleriz: The Adventure of Identity in the Triptych: Vatan, Religion and Language; R. Clogg, A Millet Within a Millet: Karamanlides; E. R. Özdemir, Borders of Belonging in the "Exchanged Generations of Karamanlis"; M. Erol, Cultural Manifestations of a Symbiosis: Karamanlidika Epitaphs of the Nineteenth Century; Ş. Ş. Şimşek, The Anatoli Newspaper and the Heyday of the Karamanlı Press; R. Anhegger, Evangelinos Misailidis ve Türkçe Konuşan Dindaşları.

11 For a critical article about the use of the term Karamanli, see F. Benlisoy \& S. Benlisoy, Türkdilli Anadolu Ortodokslarında Kimlik Algısı.

12 According to the Greek census of 1928, there were 103,642 Turcophone Christians in Greece. 50,000 of them were from Cappadocia and the others were from Pontus and other regions of Asia Minor. M. Harakopou-

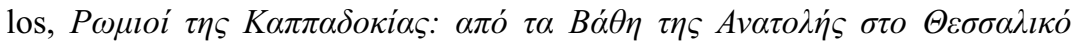

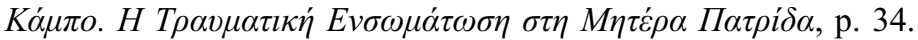

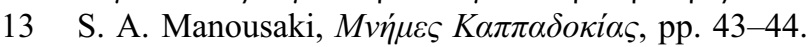

14 In this book the names "Pontus" and "Black Sea Region" are used interchangeably.

15 When I write Community with a capital "C", I mean the Greek Orthodox Community as a whole rather than a local community.

16 It does not seem proper to call the Orthodox Community in the nineteenth century an ethnic group, since they were simply a faith group, most of whose members had primitive to no ethnic consciousness that time. Here, I use the term "ethnic" from a contemporary perspective.

17 R. Dawkins, Modern Greek in Asia Minor: a Study of the Dialects of Silli, Cappadocia and Pharasa with Grammer, Texts, Translations and Glossary.

18 CAMS, Cappadocia, Gelveri, Symeon Kosmidis.

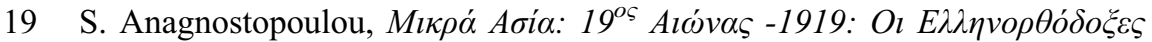

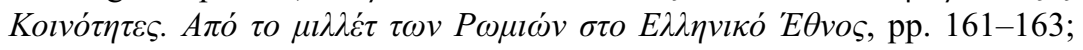


E. Balta, "Gerçi Rum isek de Rumca Bilmez Türkçe söyleriz" The Adventure of an Identity in the Triptych: Vatan, Religion and Language, p. 26.

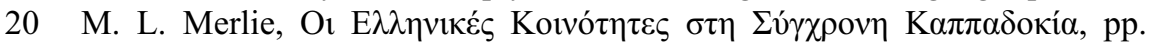
42-43.

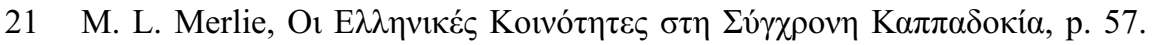
According to Xenophanes, a periodical of the "Society of Anatolians, The East," the number of Orthodox in Gelveri was three thousand five hundred by 1905 . For statistics about the inhabitants of Cappadocian settlements,

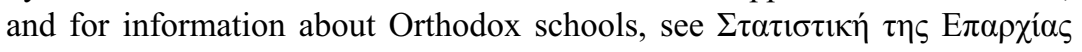

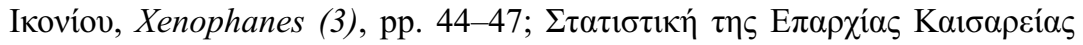

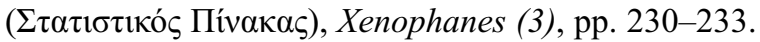

22 See P. Papailias, Genres of Recollection: Archival Poetics and Modern Greece Anthropology, History, and the Critical Imagination; E. Kapoli, Archive of Oral Tradition of the Centre for Asia Minor Studies: Its Formation and its Contribution to Research.

23 E. Kapoli, Archive of Oral Tradition of the Centre for Asia Minor Studies: Its Formation and its Contribution to Research, p. 19.

24 M. N. Layoun, Wedded to the Land? Gender, Boundaries and Nationalism in Crisis, p. 38.

25 P. Thompson, The Voice of the Past, p. 128.

26 CAMS, Cappadocia, Niğde.

27 A. Portelli, What Makes Oral History Different? p. 69.

28 CAMS, Cappadocia, Endürlük (Androniki), Evanthia Ikenderoglou.

29 CAMS, Cappadocia, Misti, Mak. Damianoglou

30 D. Walder, Post-colonial Nostalgia: Writing, Representation, Memory, p. 4.

31 S. Caunce, Sözlü Tarih ve Yerel Tarihçi, p. 26

32 T. Philipp, Bilād Al-šām in the Modern Period: Integration into the Ottoman Empire and New Relations with Europe, p. 401.

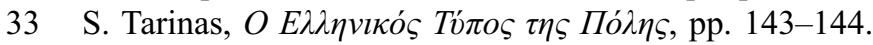

34 N. T. Soullidis. (11 December 1890). Hemşerilerimize. Anatoli, 4271; N. T. Soullidis. (5 December 1895). Anatoli Gazetesi Ser Muharriri Rifatlı Ioannis Kalfaoglou Efendi’ye. Anatoli, 5173.

\section{Chapter 1}

1 For a discussion about how memory and nostalgia generate new market opportunities, see E. Özyürek, The Politics of Public Memory in Turkey; and A. S. Alpan, But the Memory Remains: History, Memory and the 1923 Greco-Turkish Population Exchange.

2 Amy Gutmann differentiates between four different types of identity groups: cultural groups, voluntary associations, ascriptive groups and religious groups. These are neither good nor bad in and of themselves, and they should be evaluated in accordance with their affirmation of democracy and justice. See A. Gutmann, Identity in Democracy. 
3 For studies that discuss and appreciate the so called "millet system", see J. A. Sigler, Minority Rights: A Comparative Analysis; V. V. Dyke, Human Rights, Ethnicity, and Discrimination; P. Thornberry, International Law and the Rights of Minorities. For two studies that critically discuss Ottoman tolerance see W. Kymlicka, Two Models of Pluralism and Tolerance; M. Walzer, On Toleration.

4 There is confusion about either employing "tolerance" or "toleration". For Walzer, "tolerance" is an attitude or virtue; on the other hand "toleration" is a practice. In a similar way, Tyler states that "toleration" is principally a sociopolitical sanction or concession by which the majority/strong "tolerate" the weak/minority, whereas "tolerance" is an attitude and it has no relation to the power holders. For Tyler, "toleration" and "tolerance" can be employed as strategies by individuals, communities, or regimes but "toleration" is more restrictive than "tolerance" because of its limited application. Cohen, on the other hand, after conducting a detailed debate on the semantics of these two words, portrays the ambiguity of "tolerance" and claims that we do better if we reserve "toleration" for the activity, using endurance and "tolerance" for the attitude (or virtue). See M. Walzer, On Toleration, p. xi; A.Tyler, Islam, the West, and Tolerance: Conceiving Co-existence, p. 6; A. J. Cohen, What toleration is, pp. 68-95, pp. 76-77. My argument at this point is that anyone can exercise "tolerance" because it is a behavior, but not everyone is capable of "toleration" since it is an action or sanction. Since I am referring to both government policies of tolerating minorities and behavior of tolerating the Other in relation to co-existence, I use the term "tolerance" unless scholars I have quoted here use "toleration".

5 W. Brown, Regulating Aversion: Tolerance in the Age of Identity and Empire, p. 3.

6 I am particularly inspired by Michael Walzer in questions 2 and 6; and by Wendy Brown in questions 4 and 5.

7 J. S. Mill, On Liberty, p. 129.

8 I. H. Monk, Toleration and Moral Will, p. 18.

9 D. Miller, Group Identities, National Identities and Democratic Politics, p. 104.

10 A. Phillips, The Politisation of Difference: Does This Make for a More Intolerant Society? pp. 127-128.

11 W. Brown, Regulating Aversion, p. 14; p. 25.

12 W. Brown, Regulating Aversion, pp. 178-187

13 I. H. Monk, Toleration and Moral Will, p. 24.

14 P. King, Toleration, pp. 22-23; p. 60.

15 C. McKinnon, Toleration: a Critical Introduction, p. 15.

16 I. Carter, Are Toleration and Respect Compatible? p. 198.

17 H. Arendt, Human Condition, p. 243.

18 R. Sennet, Respect: The Formation of Character in an Age of Inequality, p. 23; p. 47; p. 207.

19 A. Tyler, Islam, the West and Tolerance: Conceiving Coexistence, p. 82. 
20 P. Thornberry, International Law and the Rights of Minorities, p. 29.

21 See M. Walzer, On Toleration.

22 W. Kymlicka, Two Models of Pluralism and Tolerance, p. 82.

23 A. Tyler, Islam, the West and Tolerance: Conceiving Coexistence, p. 123.

24 B. Parekh, Rethinking Multiculturalism: Cultural Diversity and Political Theory, p. 7.

25 See C. Cahen, Dhimma; C. E. Bosworth, the Concept of Dhimma in Early Islam; A. Tyler, Islam, the West and Tolerance: Conceiving Coexistence.

26 See P. Halsall, Pact of Umar, 7th Century: The Status of Non-Muslims under Muslim Rule.

27 C. Cahen, Dhimma, p. 227.

28 E. L. Daniel, Manicheanism, p. 429.

29 See H. Inalcık, The Status of the Greek Orthodox Patriarch under the Ottomans, p. 196; S. Shaw, History of the Ottoman Empire and Modern Turkey: Empire of the Gazis: The Rise and Decline of the Ottoman Empire, 1280-1808 (Vol. I), p. 151; B. Lewis, The Emergence of Modern Turkey, p. 335; B. Braude, Foundation Myths of the Millet System, p. 75.

30 See H. İnalcık, The Status of the Greek Orthodox Patriarch under the Ottomans, p. 204.

31 Kritovulos, Istanbul'un Fethi: Tarih-i Sultan Mehmet Han-ı Sani, p. 82.

32 K. B. Bardakjian, The Rise of the Armenian Patriarchate of Constantinople, p. 89; p. 91; pp. 96-97.

33 A. M. Epstein, The Leadership of the Ottoman Jews in the Fifteenth and Sixteenth Centuries, p. 103.

34 H. Inalcik, The Status of the Greek Orthodox Patriarch under the Ottomans, p. 207.

35 P. Konortas, From Ta'ife to Millet, pp. 171-172.

36 D. Stamatopoulos, From Millets to Minorities in the nineteenth Century Ottoman Empire: An Ambiguous Modernization, p. 254.

37 See A. Ozil, Orthodox Christians in the Late Ottoman Empire: A Study of Communal Relations in Anatolia, Chapter 3.

38 B. Braude, Foundation Myths of the Millet System, p. 73.

39 D. Stamatopoulos, From Millets to Minorities in the nineteenth Century Ottoman Empire: An Ambiguous Modernization, pp. 258-259.

40 Ozil makes a detailed analysis of Greek Orthodox communities in Northwestern Asia Minor and shows that structures of the koinotis (or koinotita) differed greatly from one town to another in a variety of matters, including legal, financial, material, and administrative issues. In her study, Ozil also indicates that "commune" and "community" denoted different meanings for the Greek Orthodox people: commune consisted of community leaders rather than the whole society, and it was not an institution since it lacked legal status and changed from one settlement to another; community or Rum millet meant a loose belongingness for people of the same faith. See A. Ozil, Orthodox Christians in the Late Ottoman Empire. 
41 B. Braude, Foundation Myths of the Millet System, p. 75.

42 B. Masters, Christians and Jews in the Ottoman Arab World: the Roots of Sectarianism, pp. 273-274.

43 G. Augustinos, The Greeks of Asia Minor: Confession, Community, and Ethnicity in the Nineteenth Century, pp. 188-190.

44 Ottoman tolerance can also be interpreted as governmentality in Foucaultian sense, since it is a technique or an art of the state to maintain order. According to one of its definitions, governmentality is the mentality behind three forms of power which are "sovereignty-discipline-government”. See M. Foucault, Governmentality; M. Dean, Governmentality: Power and Rule in Modern Society.

45 K. Barkey, Empire of Difference: The Ottomans in Comparative Perspective, pp. 111-112.

46 Y. Ben-Naeh, Sultanlar Diyarında Yahudiler: 17. yüzyılda Osmanlı Yahudi Toplumu, p. 105; pp. 108-109.

47 A. Tyler, Islam, the West, and Tolerance: Conceiving Co-existence, p. 121.

48 Y. Ben-Naeh, Sultanlar Diyarında Yahudiler: 17. yüzyllda Osmanlı Yahudi Toplumu, p. 112.

49 For Mahmud II's clothing regulations, see D. Quataert, Clothing Laws, State, Society in the Ottoman Empire 1770-1829.

50 R. Davison, The Millets as Agents of Change in the Nineteenth-century Ottoman Empire, pp. 321-322.

51 E. Eldem, Istanbul: from Imperial to Peripheralized Capital, p. 152.

52 D. Goffman, Izmir: from Village to Colonial Port City, p. 103.

53 E. Eldem, Istanbul: from Imperial to Peripheralized Capital, p. 154.

54 K. Barkey, Empire of Difference: the Ottomans in Comparative Perspective, p. 117.

55 Y. Ben-Naeh, Sultanlar Diyarında Yahudiler: 17. yüzyılda Osmanlı Yahudi Toplumu, p. 112; p. 118.

56 K. Barkey, Empire of Difference: The Ottomans in Comparative Perspective, p. 110; p. 113.

57 M. Campos, Ottoman Brothers: Muslims, Christians, and Jews in Early Twentieth-Century Palestine, p. 9.

58 K. Barkey, Empire of Difference: The Ottomans in Comparative Perspective, p. 114.

59 E. Gellner, Nations and Nationalism, p. 104.

60 For the cases of Sultans' zealotry, see M. D. Baer, Honored by the Glory of Islam: Conversion and Conquest in Ottoman Europe.

61 S. Deringil, Conversion and Apostasy in the Late Ottoman Empire, p. 17.

62 İ. Ortayl1, Osmanlı'da Milletler ve Diplomasi, p. 66.

63 K. Barkey, Empire of Difference: The Ottomans in Comparative Perspective, pp. 161-163. 


\section{Chapter 2}

1 For a response to such views, see A. Aktar, Debating the Armenian Massacres in the Last Ottoman Parliament, November-December 1918; S.

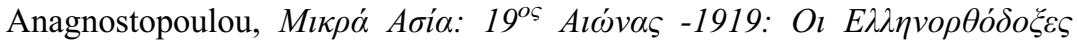

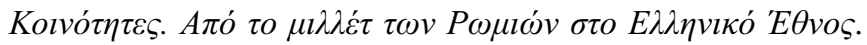

2 B. Anderson, Imagined Communities: Reflections on the Origin and Spread of Nationalism, p. 80; E. Hobsbawm, Nations and Nationalism since 1780: Programme, Myth, Reality, p. 45.

3 A. D. Smith, The Ethnic Origins of Nations, p. 17.

4 C. Tilly, Identities, Boundaries \& Social Ties, p. xiii.

5 R. M. Hayden, Antagonistic Tolerance: Competitive Sharing of Religious Sites in South Asia and the Balkans, p. 219.

6 P. Van der Veer, Religious Nationalism, p. 2. The term "religious nationalism" was first coined by the Serbian scholar M. Ekmečić in his Stvaranje Jugoslavije 1790-1818 in 1989.

7 E. Hobsbawm, Nations and Nationalism since 1780: Programme, Myth, Reality, pp. 45-77

8 F. Barth, Introduction, pp. 9-15.

9 For responses to the romantic view of co-existence in the Ottoman Empire, see A. Aktar, Debating the Armenian Massacres in the Last Ottoman Parliament, November-December 1918; S. Anagnostopoulou, Mıк $\alpha$ ́́

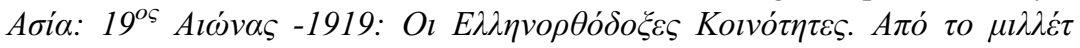

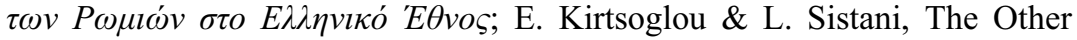
Then, the Other Now, the Other Within: Stereotypical Images and Narrative Captions of the Turk in Northern and Central Greece; R. Hirschon, Knowledge of Diversity: Towards a More Differentiated Set of "Greek” Perceptions of "Turks."

10 For more information, see www.balkantale.com/

11 R. M. Hayden \& S. Naumovic, Imagined Commonalities: The Invention of a Late Ottoman "Tradition" of Coexistence, p. 32.

12 S. Benhabib, The Embattled Public Sphere: Hannah Arendt, Juergen Habermas and Beyond, p. 5.

13 See R. Hirschon, Knowledge of Diversity: Towards a More Differentiated Set of "Greek" Perceptions of "Turks"; R. Hirschon, Heirs of the Greek Catastrophe: The Social Life of Asia Minor Refugees in Piraeus; B. Tanc, Where Local Trumps National: Christian Orthodox and Muslim Refugees since Lausanne.

14 CAMS, Cappadocia, Niğde, Konstantinos Haleplidis, Elisavet Hasirtzoglou.

15 CAMS, Cappadocia, Talas, Iordanis Giabroglou.

16 CAMS, Cappadocia, Bor, Grigorios Azariadis.

17 CAMS, Cappadocia, Bor, Sofoklis Fakidis, Dim. Haralampidis.

18 CAMS, Cappadocia, Erhilet (Erkilet), Anastasios Isaakidis.

19 CAMS, Cappadocia, Neapoli (Nevşehir), Triggidou Euf. 
20 For a detailed overview of "cosmopolitanism" literature, see W. Hanley, Grieving Cosmopolitanism in Middle East Studies.

21 N. Lessersohn, "Provincial Cosmopolitanism" in Late Ottoman Anatolia: An Armenian Shoemaker's Memoir, p. 552.

22 H. Georgelin, Armenian Inter-Community Relations in Late Ottoman Smyrna, p. 184.

23 N. Lafi, The Ottoman Cosmopolitan Hypothesis in the Light of Pheng Cheah's Critical Explorations of Cosmopolitanism.

24 H. Georgelin, Armenian Inter-Community Relations in Late Ottoman Smyrna, pp. 179-181.

25 According to demographical statistics, before the Balkan Wars (19121913 ) in the vilayet of Konya the total population was $1,101,549$. The number of Greek Orthodox was 87,021, the Turks were 988,723 and the

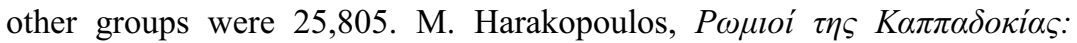

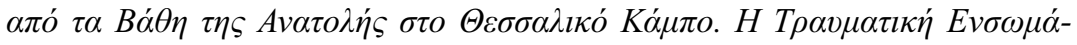

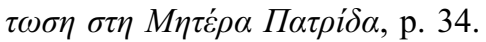

26 See E. Eldem, Istanbul: from Imperial to Peripheralized Capital; D. Goffman, Izmir: from Village to Colonial Port City; K. Barkey, Empire of Difference: The Ottomans in Comparative Perspective.

27 K. Barkey, Empire of Difference: The Ottomans in Comparative Perspective, pp. 116-117.

28 CAMS, Cappadocia, Aravan, Lioudaki?.

29 CAMS, Cappadocia, Tenei, Stefanos Yazitzoglou.

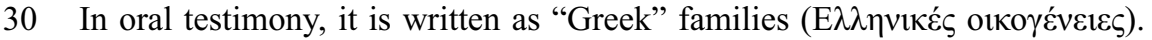
We do not know if the interviewee named her people as Yunan (Greek,

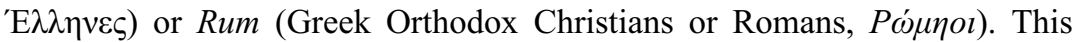
difference is important since the former refers to ethnic identity and the latter refers to religious identity. We can never know what she called her people, only that the interviewer noted it as "Greek" families.

31 CAMS, Cappadocia, Fertek, Pipina Arapoglou.

32 CAMS, Cappadocia, Rumkavak, Iosif Parlakoglou.

33 CAMS, Cappadocia, Andaval, Anas. Athanasoglou.

34 CAMS, Cappadocia, Agirnas, Alexis Sevdinoglou.

35 CAMS, Cappadocia, Zile (Kayseri), Eleutherios Iosifidis.

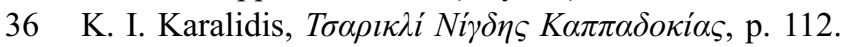

37 A. Ozil, Orthodox Christians in the Late Ottoman Empire: a Study of Communal Relations in Anatolia, p. 18.

38 A. Kojève, In Place of an Introduction, pp. 3-30.

39 C. Taylor, The Politics of Recognition, pp. 32-34; C. Tilly, Identities, Boundaries \& Social Ties, pp. 8-9; F. Barth, Introduction, pp. 9-15.

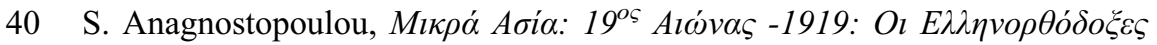

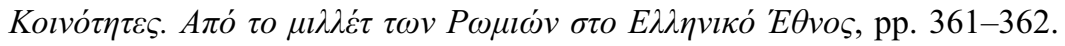

41 See R. Hirschon, Heirs of the Greek Catastrophe; E. Balta, Karamanlica Kitapların Önsözleri; E. Balta, The Adventure of an Identity in the Triptych: Vatan, Religion, Language; F. Benlisoy, S. Benlisoy, "Karamanlılar," 
“Anadolu Ahalisi” ve “Aşağı Tabakalar”: Türkdilli Anadolu Ortodokslarinda Kimlik Algısı.

42 R. Hirschon, Heirs of the Greek Catastrophe, p. 17.

43 E. Balta, Gerçi Rum isek de Rumca Bilmez Türkçe Söyleriz: The Adventure of an Identity in the Triptych: Vatan, Religion and Language, pp. 4041.

44 See Anatoli, 1891: 4280, 4287, 4288, 4295, 4297, 5440; also see I. H.

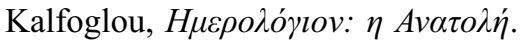

45 CAMS, Cappadocia, Limna, Anastasia Prodromou.

46 CAMS, Cappadocia, Zincidere, Iraklis Papazoglou.

47 F. Barth, Introduction, pp. 9-15.

48 CAMS, Cappadocia, Andaval, Paraskevas Ignatiadis.

49 CAMS, Cappadocia, Endürlük, Evanthia Ikenteroglou.

50 R. M. Hayden, Antagonistic Tolerance: Competitive Sharing of Religious Sites in South Asia and the Balkans, p. 207.

51 T. Bringa, Being a Muslim the Bosnian Way: Identity and Community in a Central Bosnian Village, pp. 65-79.

52 R. M. Hayden, H. Sözer, T. Tanyeri-Erdemir, A. Erdemir, The Byzantine Mosque at Trilye: a Processual Analysis of Dominance, Sharing, Transformation and Tolerance, p. 3; P. Van der Veer, Religious Nationalism, p. 28.

53 See V. L. Ménage, The Islamization of Anatolia; S. Vryonis Jr. Religious Change and Continuity in the Balkans and Anatolia from the Fourteenth through the Sixteenth Century.

54 Berlin quoted in P. Van der Veer, Syncretism, Multiculturalism si Discursul Tolerantei, pp. 198-199; P. Van der Veer, Religious Nationalism, pp. 185186.

55 See B. Aleksov, Perception of Islamization in the Serbian National Discourse, p. 120.

56 See N. Doumanis, Before the Nation: Muslim-Christian Co-Existence and its Destruction in Late Ottoman Anatolia.

57 CAMS, Cappadocia, Andaval, Paraskevas Ignatiadis.

58 CAMS, Cappadocia, Gölcük, Eleftheria Alexiadi.

59 L. Valensi, Inter-Communal Relations and Changes in Religious Affiliation in the Middle East (Seventeenth to Nineteenth Centuries), pp. 256-257.

60 M. Mazower, The Balkans, p. 55.

61 CAMS, Cappadocia, Tsouhour, Ioakeim Papadapoulou.

62 CAMS, Cappadocia, Zile-Kayseri, Eleftherios Iosifidis.

63 W. F. Hasluck, Christianity and Islam under the Sultans, pp. 43-44.

64 CAMS, Cappadocia, Gelveri, Evdoxia?.

65 CAMS, Cappadocia, Gelveri, Makrina Loukidou.

66 W. F. Hasluck, Christianity and Islam under the Sultans, pp. 564-565.

67 M. Mazower, The Balkans, p. 63.

68 CAMS, Cappadocia, Gelveri, Symeon Kosmidis. 
69 G. Bowman, Comment on R. Hayden, Antagonistic Tolerance: Competitive Sharing of Religious Sites in South Asia and the Balkans, p. 220.

70 K. Tsolakidis, Belki Bir Gün Dönerim, p. 355.

71 M. Erol, Cultural Manifestations of a Symbiosis: Karamanlidika Epitaphs of the Nineteenth Century, p. 92.

72 Busbecq quoted in M. Mazower, The Balkans, p. 59.

73 CAMS, Cappadocia, Andaval, Paraskevas Ignatiadis.

74 For more on the Islamization of Anatolia, see S. Vryonis Jr., The Decline of Medieval Hellenism in Asia Minor and the Process of Islamization from the

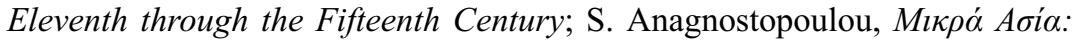

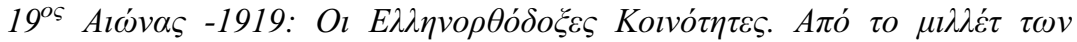

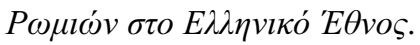

75 P. Van der Veer, Religious Nationalism, p. 43.

76 E. Balta, Gerçi Rum isek de Rumca Bilmez Türkçe Söyleriz: The Adventure of an Identity in the Triptych: Vatan, Religion and Language, p. 29.

77 CAMS, Cappadocia, Zile-Kayseri, Eleftherios Iosifidis.

78 CAMS, Cappadocia, Tsouhour, Ioakeim Papadopoulou.

79 R. Hirschon, Heirs of the Greek Catastrophe: the Social Life of Asia Minor Refugees in Piraeus, p. 21.

80 R. M. Hayden, H. Sözer, T. Tanyeri-Erdemir \& A. Erdemir, The Byzantine Mosque at Trilye: a Processual Analysis of Dominance, Sharing, Transformation and Tolerance, p. 3.

81 M. N. Layoun, Wedded to the Land? Gender, Boundaries and Nationalism in Crisis, p. 42.

82 Anatoli, October 16, 1851, 39.

83 CAMS, Cappadocia, Zile, Kayseri, Eleftherios Iosifidis.

84 CAMS, Cappadocia, Limna, Anastasia Prodromou.

85 B. Aleksov, Perception of Islamization in the Serbian National Discourse, p. 113.

86 CAMS, Cappadocia, Zincidere, Maria?.

87 CAMS, Cappadocia, Tsouhour, Sofia Koutlidou.

88 S. Deringil, Conversion and Apostasy in the Late Ottoman Empire, p. $3 ;$ p .4.

89 Y. Friedmann, Tolerance and Coercion in Islam: Interfaith Relations in the Muslim Tradition, p. 161.

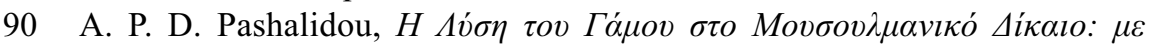

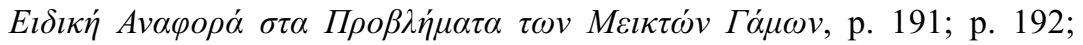
p. 221.

9110 and 31 of Laodicea, 21 of Carthage [419], 14 of Chalcedon and 72 of Trullo address the issue of "interchurch marriage," or marriage with a non-Orthodox Christian. Characteristically, the normative canon 72 of Trullo states: "An Orthodox man is not permitted to marry a heretical woman, nor an Orthodox woman to be joined to a heretical man." Marriage with a non-Christian or non-believer is not mentioned at all, except in the case of pre-existing marriage, where either one of the spouses had subsequently espoused the Orthodox faith. The continuation of such 
marriage is permissible, according to the teaching of St. Paul (I Cor 7, 12-14), if so willed by the adherent spouse. See, L. J. Patsavos, C. J. Joanides, Interchurch Marriages: An Orthodox Perspective.

92 L. J. Patsavos, C. J. Joanides, Interchurch Marriages: An Orthodox Perspective, pp. 434-435.

93 CAMS, Cappadocia, Tsouhour, Ioakeim Papadapoulou.

94 For a detailed study about conversion, see S. Deringil, Conversion and Apostasy in the Late Ottoman Empire; S. Deringil, "There is No Compulsion in Religion": Conversion and Apostasy in the Late Ottoman Empire 1839-1856.

95 S. Deringil, Conversion and Apostasy in the Late Ottoman Empire, p. 18.

96 During the Tanzimat era, non-Muslims could receive permits to build churches, schools and charity organizations relatively easily in comparison to previous years. However, there was not total freedom on this issue; they had to continue to ask for permission in the old way. See I. Ortayl1, Osmanlı'da Milletler ve Diplomasi, p. 63.

\section{Chapter 3}

1 İ. Ortaylı, Imparatorluğun En Uzun Yüzyılı, p. 48.

2 V. Roudometof, From Rum Millet to Greek Nation: Enlightenment, Secularization, and National Identity in Ottoman Balkan Society, 1453-1821, p. 32.

3 A. D. Smith, Nationalism and Modernism: A Critical Survey of Recent Theories of Nations, p. 17.

4 See E. Gellner, Nations and Nationalism; E. Hobsbawm, Nations and Nationalism since 1780: Programme, Myth, Reality; B. Anderson, Imagined Communities: Reflections on the Origin and Spread of Nationalism; D. Stamatopoulos, From Millets to Minorities in the $19^{\text {th }}$ Century Ottoman Empire: an Ambiguous Modernization, p. 253.

5 P. Van der Veer, Religious Nationalism, p. 15.

6 A. Smith, Nationalism and Modernism: A Critical Survey of Recent Theories of Nations, pp. 45-46.

7 E. Gazi, Revisiting Religion and Nationalism in Nineteenth-Century Greece, p. 95.

8 P. Van der Veer, Religious Nationalism, p. 2.

9 H. Erdem, "Do not Think of the Greeks as Agricultural Laborers": Ottoman Responses to the Greek War of Independence, p. 81.

10 See B. Anderson, Imagined Communities: Reflections on the Origin and Spread of Nationalism, p. 88; P. Mackridge, Language and National Identity in Greece 1766-1976, p. 44; U. Özkırıml1, \& S. A. Sofos, Tormented by History: Nationalism in Greece and Turkey, p. 22.

11 D. Stamatopoulos, From Millets to Minorities in the $19^{\text {th }}$ Century Ottoman Empire: An Ambiguous Modernization, p. 255. 
12 P. Mackridge, Language and National Identity in Greece 1766-1976, p. 33.

13 For the issue of "Russian Expectation," see P. Kitromilides, Enlightenment and Revolution: The Making of Modern Greece; P. Kitromilides, Enlightenment, Nationalism and Orthodoxy: Studies in the Culture and Political Thought of Southeastern Europe.

14 E. Gazi, Revisiting Religion and Nationalism in Nineteenth-Century Greece, p. 96.

15 T. G. Tatsios, The Megali Idea and the Greek-Turkish War of 1897: The Impact of the Cretan Problem on Greek Irredentism, 1866-1897, p. 13.

16 A. Koraes, Report on the Present State of Civilization in Greece, pp. $158-159$.

17 T. G. Tatsios, The Megali Idea and the Greek-Turkish War of 1897: The Impact of the Cretan Problem on Greek Irredentism, 1866-1897, p. 10.

18 V. Roudometof, From Rum Millet to Greek Nation: Enlightenment, Secularization, and National Identity in Ottoman Balkan Society, 1453-1821, pp. 28-29, 30, 33.

19 U. Özkırıml, \& S. A. Sofos, Tormented by History: Nationalism in Greece and Turkey, p. 78, 83. Byzantium was not rehabilitated into school manuals until the end of the nineteenth century, the Byzantine Museum was not founded until 1914, and the first professors of Byzantine Art and Byzantine History were only appointed at the University of Athens in 1912 and 1924, respectively; appropriation of the Middle Ages with Greek national historiography took some time. Koulouri \& Kiousopoulou quoted in A. Liakos, Hellenism and the Making of Modern Greece: Time, Language, Space, pp. 209-210.

20 I. N. Grigoriadis, Instilling Religion in Greek and Turkish Nationalism: A "Sacred Synthesis," pp. 3, 32-35.

21 U. Özkırımlı, \& S. A. Sofos, Tormented by History: Nationalism in Greece and Turkey, p. 23.

22 T. G. Tatsios, The Megali Idea and the Greek-Turkish War of 1897: The Impact of the Cretan Problem on Greek Irredentism, 1866-1897, p. 3.

23 C. K. Tuckerman, The Greeks of To-day, p. 124.

24 K. P. Tsolainos, Greek Irredentism, p. 160.

25 P. Mackridge, Language and National Identity in Greece 1766-1976, p. 34.

26 T. G. Tatsios, The Megali Idea and the Greek-Turkish War of 1897: The Impact of the Cretan Problem on Greek Irredentism, 1866-1897, p. 10.

27 R. Clogg, The Greek Millet in the Ottoman Empire, p. 186.

28 V. Roudometof, From Rum Millet to Greek Nation: Enlightenment, Secularization, and National Identity in Ottoman Balkan Society, 1453-1821, p. 21.

29 I. N. Grigoriadis, Instilling Religion in Greek and Turkish Nationalism: a "Sacred Synthesis," p. 36. 
30 D. Stamatopoulos, From Millets to Minorities in the $19^{\text {th }}$ Century Ottoman Empire: An Ambiguous Modernization, p. 266.

31 D. Livanios, Making Borders, Unmaking Identities: Frontiers and Nationalism in the Balkans, 1774-1913, p. 16.

32 R. Clogg, Anadolu Hıristiyan Karındaşlarımız: The Turkish Speaking Greeks of Asia Minor, p. 79.

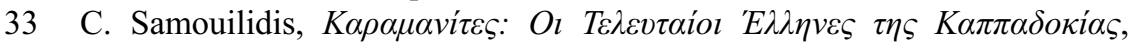
pp. $22-24$.

34 Karolidis quoted in R. Dawkins, Modern Greek in Asia Minor: a Study of the Dialects of Silli, Cappadocia and Pharasa with Grammar, Texts, Translations and Glossary, p. 11.

35 CAMS, Cappadocia, Andaval, Paraskevas Ignatiadis.

36 CAMS, Cappadocia, Andaval, Makrina Karadagli.

37 CAMS, Cappadocia, Limna, Anastasia Prodromou.

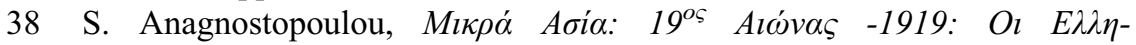

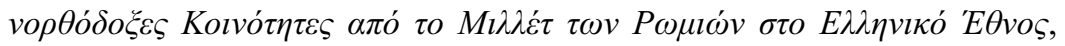
pp. 230-231.

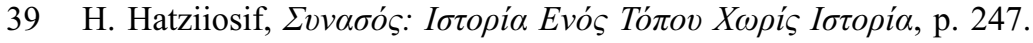

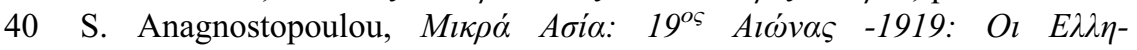

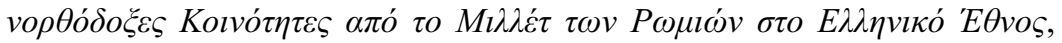
pp. 234-235.

41 S. Zandi-Sayek, Ottoman Izmir: The Rise of a Cosmopolitan Port, 1840/1880, p. 5, 24.

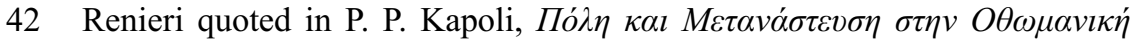

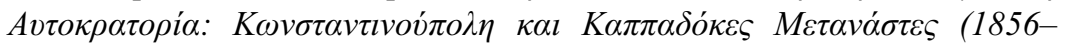
1908), p. 58.

43 G. Augustinos, The Greeks of Asia Minor: Confession, Community, and Ethnicity in the Nineteenth Century, p. 80.

44 Y. D. Çetinkaya, The Young Turks and the Boycott Movement: Nationalism, Protest and the Working Classes in the Formation of Modern Turkey, p. 15.

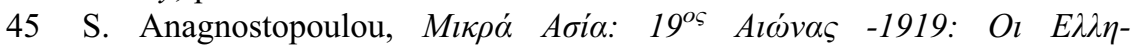

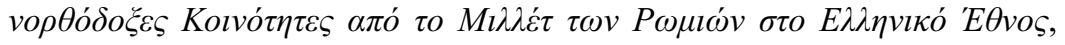
p. 237.

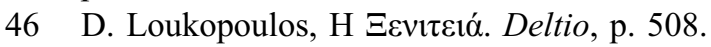

47 CAMS, Cappadocia, Andaval, Paraskevas İgnatiadis.

48 CAMS, Cappadocia, Aravan, Haralambos Koumr.?

49 CAMS, Cappadocia, Andaval, Haralambos Pasalis.

50 CAMS, Cappadocia, Endürlük, Isaak Karamanoglou.

51 CAMS, Cappadocia, Vexe, Evgenia Tokatloglou.

52 CAMS, Cappadocia, Vexe, Lazaros Farsakoglou.

53 CAMS, Cappadocia, Moutalaski, P. Kiostoglou, Lioudakis Oktovrios.

54 CAMS, Cappadocia, Moutalaski, P. Kioseoglou.

55 CAMS, Cappadocia, Kesi, V. Leontiadis. 
56 CAMS, Cappadocia, Ai Konstantinos, Iordanis Aleksandridis, Pantelis Lazaridis.

57 CAMS, Cappadocia, Prokopi, Eustathios Hatzieuthimiadis.

58 CAMS, Cappadocia, Poros, Ioannis Kamalakidis, Amfil. Amfilokiadis.

59 CAMS, Cappadocia, Tsouhour, Kostas Misailidis, Iak. Hairoglou.

60 CAMS, Cappadocia, Erkilet, Anastasios Isakidis.

61 CAMS, Cappadocia, Tenei, Kurillos Terkendoglou.

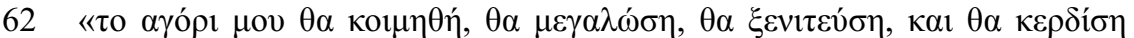

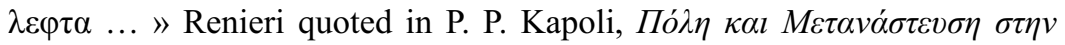

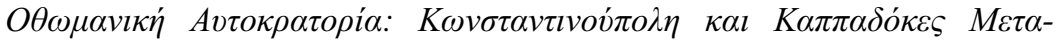
vá $\sigma \tau \varepsilon \varsigma$ (1856-1908), p. 27.

63 As a consequence of male immigration and high rates of maternal mortality during child birth and pregnancy, there were too many orphans in Cappadocia. In the latest years of Christian presence in Cappadocia, in some settlements many women were saved by the doctors who studied abroad and came back to serve their communities. K. Nikolaidou-Danasi,

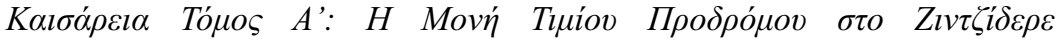

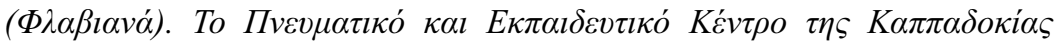

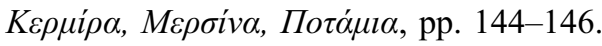

64 A title of respect used for men.

65 "A ğam sen gideli üç yıl oldu. Diktiğin fidanlar hep meyve verdi. Seninle giden ağalar geldi. Tez gel ağam, tez gel elvermiyor mu? Zalim gurbet sana yol vermiyor mu?" CAMS, Cappadocia, Gelveri, D. Loukidou, M. Haztzopoulou. For the female songs about foreign lands, see. G. Göktürk, Zalim Gurbet Sana Yol Vermiyor mu? Geride Kalan Ortodoks Kadınların Gözünden Gurbetliğe Bakış.

66 I. Limnidis. (July 16, 1888). Anatol'da İlm Niçin İleri Gitmiyor? Terakki, 5.

67 I. Limnidis. (August 15, 1888). Anatol'da İlm Niçin İleri Gitmiyor? Terakki, 7.

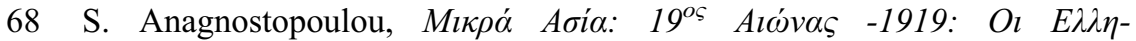

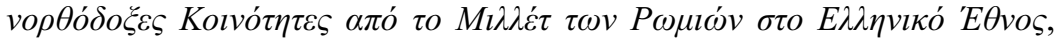
p. 238.

69 D. Livanios, Making Borders, Unmaking Identities: Frontiers and Nationalism in the Balkans, 1774-1913, p. 10.

70 D. Kamouzis, Elites and the Formation of National Identity, p. 16, 19.

71 P. Kitromilides, Greek Irredentism in Asia Minor and Cyprus, p. 7.

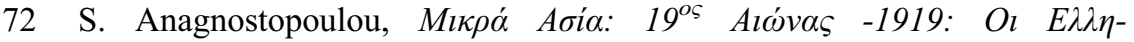

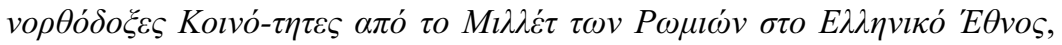
p. 371.

73 See G. Augustinos, The Greeks of Asia Minor: Confession, Community, and Ethnicity in the Nineteenth Century.

74 A. Ozil, Orthodox Christians in the Late Ottoman Empire: A Study of Communal Relations in Anatolia, p. 122. 


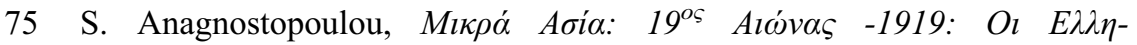

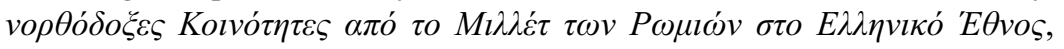
pp. 325-326, 361-364.

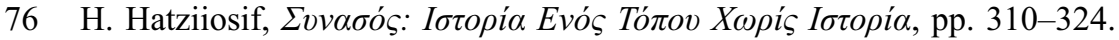

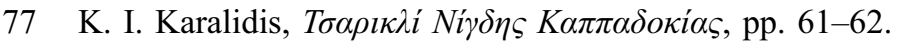

78 S. Benlisoy, F. Benlisoy, 19. Yüzyılda Karamanlılar ve Eğitim: Nevşehir Mektepleri, p. 25.

79 CAMS, Cappadocia, Gelveri, K. Sotyropoulos, G. Dopridis.

80 CAMS, Cappadocia, Tenei, Efterpi Koursoglou, Stefanos Giapitzoglou, A. Kuriomidis.

81 CAMS, Cappadocia, Neapoli, Vithleem Kalavoutsoglou, Foteini Georgiadou, Evronia Georgiadou, Marika Trellopoulou.

82 CAMS, Cappadocia, Moutalaski, Mihail Giavroglou, P. Kiostoglou.

83 CAMS, Cappadocia, Prokopi, Efstathios Hatziefthimiadis, Georgios Isaakidis.

84 There was a school for the Muslims at the Turkish neighborhood as well as a separate school for the Protestants. The fact that the schools coalesced with the church affiliation confirms the competition at inter-

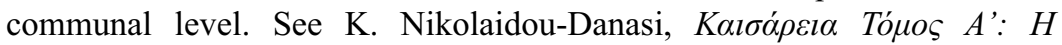

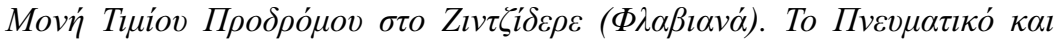

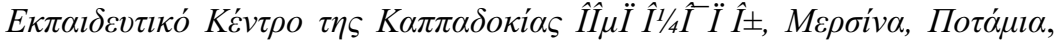
p. 41.

85 S. Benlisoy, Education in the Turcophone Orthodox Communities of Anatolia during the Nineteenth Century, pp. 102, 254-255.

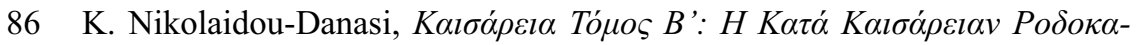

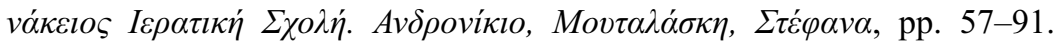
Also for the teachers of the Theological Seminary, see the same book, pp. 35-52, 463-516.

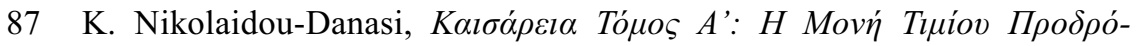

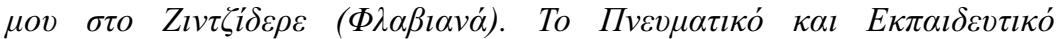

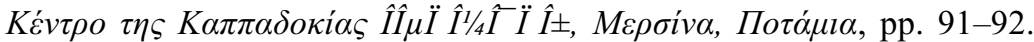

88 Kayseriye'deki Kappadokiki Ieratiki Sholi. (March 12, 1895). Anatoli, 5012.

89 CAMS, Cappadocia, Tenei, A. Kuriomidis.

90 CAMS, Cappadocia, Zile-Kayseri, Eleftherios Hatzipetros.

91 CAMS, Cappadocia, Gesi, D. Manolaka.

92 Anatol'da Hemcinslerimiz Rumca Tahsilinde Niçin Suupet Çekiyorlar? (September 30, 1888). Terakki, 10.

93 For statistics about schools I used refugee testimonies because they gave the latest information about the schools. Another source for education statistics was Xenophanes; however it only informs us about the years

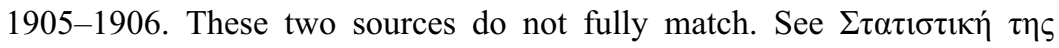

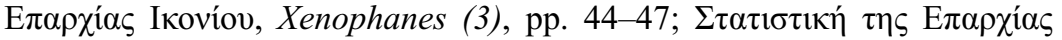

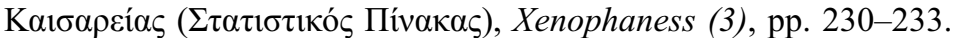

94 CAMS, Cappadocia, Gelveri, K. Sotiropoulos, G. Dopridis. 
95 CAMS, Cappadocia, Gölcük-Limna, Neofitos Apostolidis, Kosmas Serafimidis.

96 Biz teba-i şahaneden ve ez cümle alış-veriş içinde bulunuyoruz. Ahz-u itamızın yüzde doksan dokuzu Türkçe'dir. Niçin yazıp okumayalım? [ ... ] Niçin her dükkanda bir Türkçe yazıp okuyan bulunmasın? [...] Mekteplerde Astronomia veyahud teologia okutmaktan ise lisan-1 Türki'yi layıkı ile belletmek daha evliyadır.Y. Gavriilidis, (January 24, 1891)

Nevşehirlilere Hem Tavsiye Hem Rica. Anatoli, 4288.

97 "Lisan-1 Osmani'yi tahsil etmek arzusunda bulunanlara az vakit zarfinda yeni usul üzere tarif olunur. Arzu edenler gazetemize müracaat etsinler." Anatoli, February 21, 1895, 4948.

98 Papastathis quoted in A. Kazamias, The Education of the Greeks in the Ottoman Empire, 1876-1923: A Case Study of "Controlled Toleration," pp. 354, 355.

99 R. Clogg, The Greek Millet in the Ottoman Empire, pp. 195-199.

100 See D. Kamouzis, Elites and the Formation of National Identity, pp. 2022, 29, 37. Also see G. Vassiadis, The Syllogos Movement of Constantinople and Ottoman Greek Education 1861-1923, pp. 51, 60-65.

101 See G. Vassiadis, The Syllogos Movement of Constantinople and Ottoman Greek Education 1861-1923, pp. 209-210, 230-236. Also see A. Kazamias, The Education of the Greeks in the Ottoman Empire, 1876-1923: A Case Study of "Controlled Toletation," p. 355.

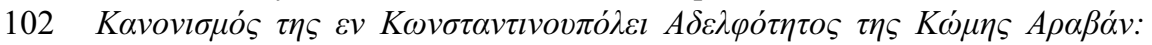

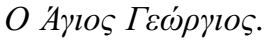

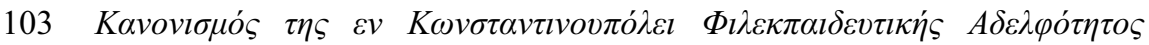

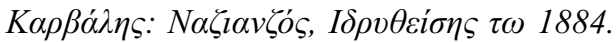

104 S. Benlisoy, İstanbul'da Yaşayan Nevşehirli Ortodokslar Tarafından Kurulan Papa Yeorgios Nam Cemiyet-i Islahiyyesi, p. 37.

105 S. Benlisoy, İstanbul'a Göçmüş Ürgüplü Ortodoksların Kurduğu Bir Cemiyet: "Areti” Maarifperveran Cemiyeti, p. 7.

106 CAMS, Cappadocia, Tenei, Efterpi Koursoglou, Stefanos Giapitzoglou.

107 Dahiliye. (January 22, 1891). Anatoli, 4287.

108 “[ ... ] Gözümüzü açalım. Bundan böyle biz bize kalmıyoruz. Anadolumuzda demir yolları yapılıyor. Geçim için ta Amerika'dan memleketimize ademler gelecektir. Cahil kalır isek hizmetçilikten başka işe yaramayacağ1z [ ... ]" Anadolumuzun Mektepleri. Anatoli, February 24, 1891, 4295.

109 S. Benlisoy, Education in the Turcophone Orthodox Communities of Anatolia during the Nineteenth Century, p. 116.

110 A. Kazamias, The Education of the Greeks in the Ottoman Empire, 1876-1923: a Case Study of “Controlled Toletation," p. 362.

111 For a list of prominent people of Asia Minor, see Ch. A. Theodoridou,

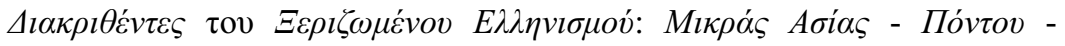
Av. $\Theta \rho \dot{\alpha} \kappa \eta \varsigma-K \omega v \sigma \tau \alpha v \tau \iota v o v \pi o ́ \lambda \varepsilon \omega \varsigma$, Tó $\mu о \varsigma$ B'.

112 Other deputies of Cappadocian origin were Pant. Kosmidis (Istanbul, 1908-1912); Mihalakis Stelios (Limni, 1908-1913); Anas. Mihailidis 
(Izmit, 1908-1918); Georg. Kourtoglou (Niğde, 1908-1912); Aris. Georgantzoglou; (İzmir, 1908-1911); Ananias Kalinoglou (Niğde, 19121918); Theod. Arzoglou (Samsun, 1914-1918); I. Gkevenidis (Karahisar, 1914-1918); Vang. Meymeroglou (İzmir, 1914-1918); Vikt. Tsormpatzo-

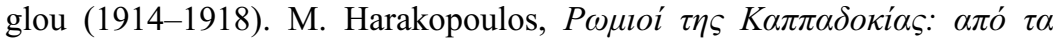

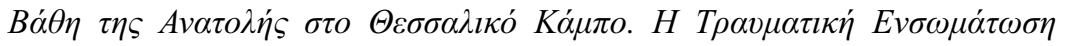
$\sigma \tau \eta M \eta \tau \dot{\varepsilon} \rho \alpha$ П $\alpha \tau \rho i ́ \delta \alpha$, p. 50.

113 CAMS, Cappadocia, Niğde, Alexandros Yagtzoglou. For his short biography,

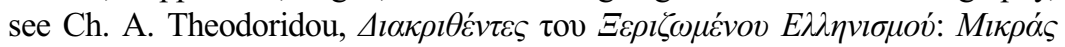

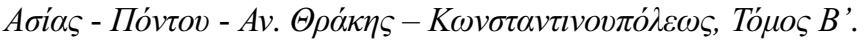

114 V. Kechriotis, Osmanlı İmparatorluğu'nun Son Döneminde Karamanlı Rum Ortodoks Diasporası: Izmir Mebusu Emmanuil Emmanuilidis, p. 39. For the English version of this article, see. V. Kechriotis, Ottomanism with a Greek Face: Karamanli Greek Orthodox Diaspora at the End of the Ottoman Empire.

115 See V. Kechriotis, Ottomanism with a Greek Face: Karamanli Greek Orthodox Diaspora at the End of the Ottoman Empire; V. Kechriotis, Atina'da Kapadokyalı, İzmir'de Atinalı, İstanbul'a Mebus: Pavlos Karolidis'in Farklı Kişilik ve Aidiyetleri; Ch. A. Theodoridou,

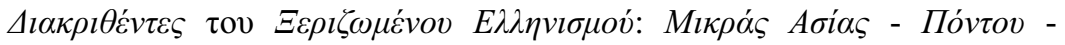

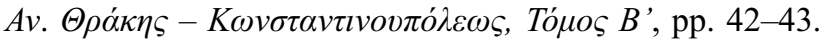

116 C. Boura, The Greek Millet in Turkish Politics: Greeks in the Ottoman Parliament (1908-1918), p. 195.

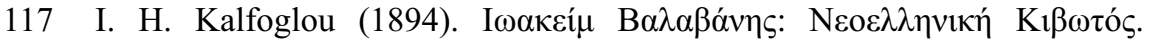

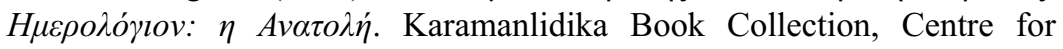
Asia Minor Studies.

118 Valavanis quoted in R. Clogg, Anadolu Hıristiyan Karındaşlarımız, p. 67.

119 E. Balta, Karamanli Press Smyrna 1845- Athens 1926, pp. 109-110.

120 See M. Erol, Evangelinos Misailidis; E. Balta, Gerçi Rum Isek de Rumca Bilmez Türkçe Söyleriz: The Adventure of an Identity in the Triptych: Vatan, Religion and Language.

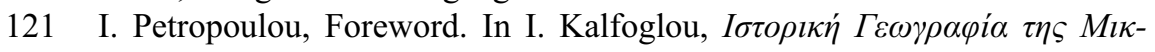

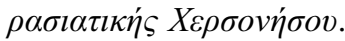

122 Many distinguished people taught at the Theological Seminary in Zincidere. One of them was Ilias Emmanouilidis. Being originally from Zincidere, Emmanouilidis was also a medical doctor. Anastasios Nikolaidis, as another distinguished figure, was born in Kermira in a Turcophone family. After completing the Theological Seminary and the gymnasium of Chios, he worked as a teacher in his home town Kermira and afterwards in Moutalaski and Mersina. For the teachers of the Seminary and

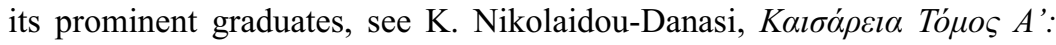

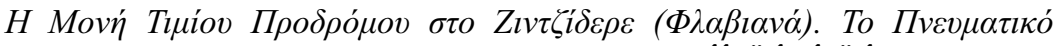

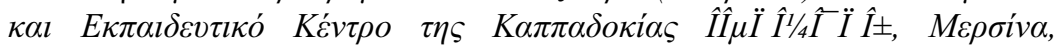

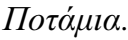




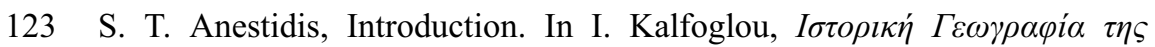

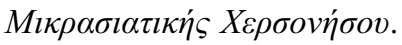

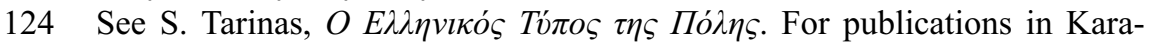
manlidika; E. Balta, Karamanlidika: Nouvelles Additions et Complements I; E. Balta, Karamanlidika: XXE siècle: Bibliographie Analytique; E. Balta, Karamanlidika: Additions (1584-1900); E. Balta, Karamanli Press Smyrna 1845- Athens 1926; E. Balta \& Matthias Kappler,(Eds.),Cries and Whispers in Karamanlidika Books.

125 E. Misailidis. (December 11, 1851). Ak1l Potas1 Nedir? Sholeion'dur! Anatoli, 47.

126 An anonymous letter from Kermira. (October 28, 1852). Anatoli, 90.

127 Dahiliye. (April 8, 1852). Anatoli, 62.

128 Dahiliye. (January 22, 1891). Anatoli, 4247.

129 Kayseriye'deki Kappadokiki Ieratiki Sholi. (March 12, 1895). Anatoli, 5012.

130 Ş. Ş. Şimşek, The Anatoli Newspaper and the Heyday of the Karamanlı Press, p. 117.

131 I. I. Kalfoglous. (August 31, 1895). Ilimperver Anadolululara. Anatoli, 5097.

132 Anatoli Neden Terakki etmiyor? (December 4, 1895). Anatoli, 5172.

133 Hemşehrilerimize. (February 7, 1891). Anatoli, 4293.

134 N. Soullidis. (December 5, 1895). Anatoli Gazetesi Ser Muharriri Rifatlı Ioannis Kalfaoglou Efendi'ye. Anatoli, 5173.

135 A. Grigoriadis. (December 8, 1895). Anatoli'nin Devamına Lüzum Var mi Yok mu? Anatoli, 5175.

136 I. Sadeoglou. (February 26, 1896). İzhar Hissiyat. Anatoli, 5235.

137 Erbab-1 Mütalaaya. (May 15, 1888). Terakki, 1.

138 Bir Mektup: Terakki İdaresine. (June 30, 1888).Terakki, 4.

139 M. I, Portakaloglou. (May 15, 1888). Terakki. Terakki, 1.

140 For an article about Terakki, see M. Orakçı (2014). Karamanlıca Bir Gazete: Terakki.

141 “Eğer Terakki'nin neşrinden maksat ulum-u maarife hizmet ise, bunu orta derecede bir lisan tasvir etmek lazımdır, ta ki Anadolulu yazılan şeyden fikir ala, hem de aynı zamanda, az bildiği veya hiç bilmediği Osmanlıca lisanını da öğrenmiş ola.” Bafralı Yanko. (September 30, 1888). Muharrerat: 8. Nüshadan Mabat. Terakki, 10.

142 B. Anderson, Imagined Communities: Reflections on the Origin and Spread of Nationalism, p. 36.

\section{Chapter 4}

1 See Maria Porloglou Kosmidou, Kermira; Eleni Serafeimidou, Zincidere; Annika Haritonidou, Gesi, $H^{\prime} E \xi o \delta o \varsigma$, Tó $\mu о \varsigma$ B', pp. 67, 83, 92; K. Nikolai-

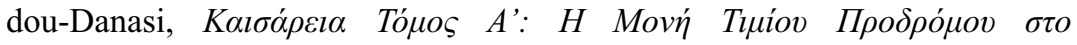




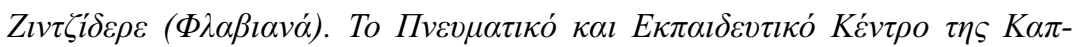

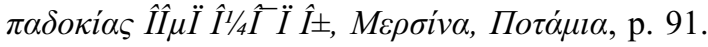

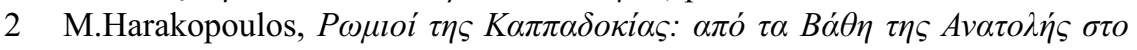

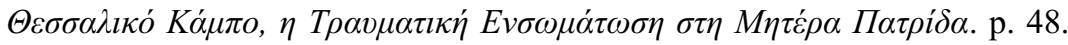

3 See E. Ahladi, İzmir'de İttihatçılar ve Rumlar: Yunan-Rum Boykotu (1908-1911).

4 See Y. G. Mourelos, The 1914 Persecutions and the First Attempt at an Exchange of Minorities Between Greece and Turkey.

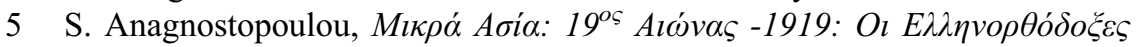

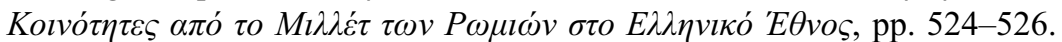

6 Y. D. Çetinkaya, The Young Turks and the Boycott Movement: Nationalism, Protest and the Working Classes in the Formation of Modern Turkey, pp. 90, 119-120.

7 See E. Emmanuilidis, Osmanlı İmparatorluğunun Son Yllları.

8 CAMS, Cappadocia, Bor, Sofoklis Fakidis, Dim. Haralambidis.

9 CAMS, Cappadocia, Bor, Papakostis Papadopoulos.

10 H. Exertzoglou, The Development of a Greek Ottoman Bourgeoisie: Investment Patterns in the Ottoman Empire, 1850-1914, p. 100.

11 E. Emmanuilidis, Osmanl Imparatorluğunun Son Yılları, p. 153.

12 See Y. G. Mourelos, The 1914 Persecutions and the First Attempt at an Exchange of Minorities Between Greece and Turkey; M. Bjørnlund, The 1914 Cleansing of Aegean Greeks.

13 M. Bjørnlund, The 1914 Cleansing of Aegean Greeks, p. 47.

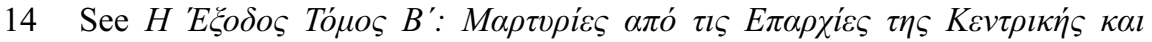

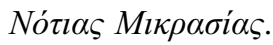

15 R. Gingeras, Sorrowful Shores: Violence, Ethnicity, and the End of the Ottoman Empire, 1912-1923, p. 40.

16 CAMS, Cappadocia, Limna-Gölcük, Mihail Savvidis.

17 CAMS, Cappadocia, Nigdi-Niğde, Konstantinos Haleplidis Elisavet Hasirtzoglou.

18 CAMS, Cappadocia, Ağırnas, Avraam Avramidis.

19 CAMS, Cappadocia, Zincidere, Katina Piniatoglou.

20 The amount of the tax in lieu of military service paid by Muslims and non-Muslims was unequal (8000 kurus and 5000 kurus, respectively). One from every 180 non-Muslim men were to be conscripted. Therefore, 180 people paid the tax of one man. In the end, the amount paid by every nonMuslim was more or less equal to previously collected jizya (cizye) tax. See U. Gülsoy, Cizyeden Vatandaşlĭga: Osmanlı'nın Gayrimüslim Askerleri, pp. 85-101.

21 U. Gülsoy, Cizyeden Vatandaşlığa: Osmanlı'nın Gayrimüslim Askerleri, pp. 141-144; M. Hacisalihoğlu, Osmanlı İmparatorluğunda Zorunlu Askerlik Sistemine Geçiş: Ordu-Millet Düşüncesi, p. 63.

22 U. Gülsoy, Cizyeden Vatandaşlığa: Osmanlı'nın Gayrimüslim Askerleri, pp. 156, 171. 


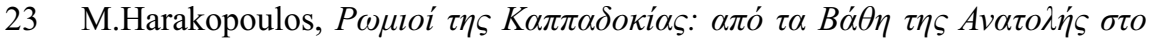

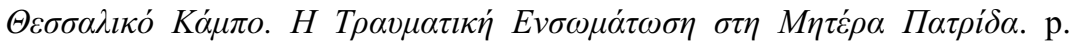
65.

24 U. Gülsoy, Cizyeden Vatandaşlı̆̆a: Osmanlı’nın Gayrimüslim Askerleri, p. 156.

25 See E. J. Zürcher, The Ottoman Conscription System In Theory And Practice, 1844-1918.

26 See G. Kritikos, Motives for Compulsory Exchange.

27 Cemal quoted in U. Gülsoy, Cizyeden Vatandaşlığa: Osmanlı'nın Gayrimüslim Askerleri, p. 156.

28 CAMS, Cappadocia, Prokopi, Eust. Eu8imiadis, Elisavet Isaakidou.

29 CAMS, Cappadocia, Tynana, Vas. Seferiadis.

30 CAMS, Cappadocia, Misti, Mak. Damianoglou.

31 CAMS, Cappadocia, MistiGeorg. Mpolasih.?

32 CAMS, Cappadocia, Limna, Kosmas Serafeimidis.

33 CAMS, Cappadocia, Karatzoren, Ioannis Misailoglou.

34 CAMS, Cappadocia, Zile, Eleftherios Iosifidis.

35 CAMS, Cappadocia, Akso, Dimitrios Misailidis.

36 CAMS, Cappadocia, Niğde, Aleksandros Giagtzoglou.

37 I am particularly inspired by Jay Winter's lecture entitled "Sites of Memory, Sites of Mourning" in Open Yale courses for the class "History 202: European Civilization, 1648-1945" in this paragraph.

38 See F. Benlisoy, S. Benlisoy, Türk Milliyetçiliğinde Katedilmemiş bir Yol: 'Hiristiyan Türkler've Papa Eftim, pp. 25-32.

39 See Papa Efthim Efendi'nin Orthodoxos Ahaliye Müracaatı ve Patrikhaneye Karşı Müdafaanamesi, pp. 1-19.

40 F. Benlisoy, S. Benlisoy, Türk Milliyetçiliğinde Katedilmemiş bir Yol: "Hıristiyan Türkler" ve Papa Eftim, pp. 67, 102, 137.

41 F. Benlisoy, S. Benlisoy, Türk Milliyetçiliğinde Katedilmemiş bir Yol: "Hıristiyan Türkler" ve Papa Eftim, pp. 42-48.

42 The Orthodox Churches in Greece, Romania, Bulgaria, and Albania declared their independence or autocephality unilaterally in 1833,1865 , 1870 and 1922-1937 respectively. F. Benlisoy, S. Benlisoy, Türk Milliyetçiliğinde Katedilmemiş bir Yol: 'Hıristiyan Türkler' ve Papa Eftim, p. 53.

43 CAMS manuscripts, Galatia, Keskin Maden, Nikos Fotiadis.

44 CAMS, Cappadocia, Neapoli-Nevşehir, Sofronia Georgiadou.

45 CAMS, Galatia, Keskin Maden, K. Giorgiadis.

46 CAMS, Cappadocia, Prokopi, Sythimios Sofoulis.

47 See H. J. Psomiades, The Oecumenical Patriarchate under the Turkish Republic: The First Ten Years, pp. 61-62; T. Ergene, Istiklal Harbinde Türk Ortodokslarl, pp. 25-26.

48 R. Clogg, Anadolu Hıristiyan Karındaşlarımız: The Turkish-Speaking Greeks of Asia Minor, p. 82. 
49 See O. Yıldırım, Diplomacy and Displacement, pp. 75-76; H. J. Psomiades, The Oecumenical Patriarchate under the Turkish Republic: the First Ten Years, p. 62.

50 R. Clogg, Anadolu Hıristiyan Karındaşlarımı: the Turkish-Speaking Greeks of Asia Minor, p. 83.

\section{Chapter 5}

1 For such scholarship, see H. Ertuğrul, Azınlık ve Yabancı Okullarının Türk Toplumuna Etkisi; İ. P. Haydaroğlu, Osmanl Imparatorluğunda Yabancı Okullar; H. Özsoy, Kayseri'de Amerikan Misyoner Faaliyetleri ve Talas Amerikan Koleji.

2 For a nineteenth century source concerning Orthodox reaction to Protest-

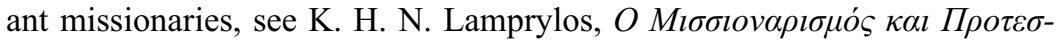

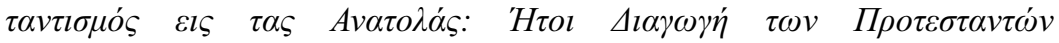

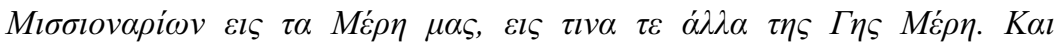

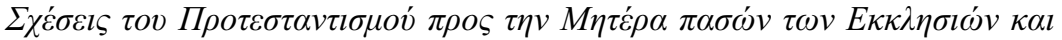

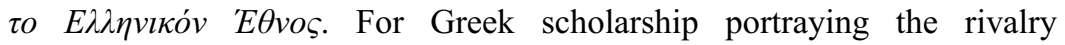
between the missionaries and the Patriarchate, or the autocephalous

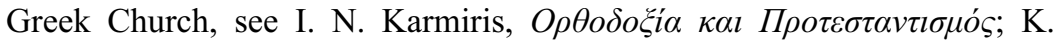

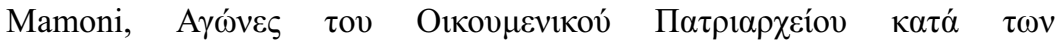

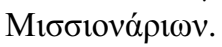

3 See U. Makdisi, Artillery of Heaven: American Missionaries and the Failed Conversion of the Middle East, pp. 61-62.

4 For "Turkish Protestants" and the curious case of the apostate Ahmet Tevfik, see S. Deringil, Conversion and Apostasy in the Late Ottoman Empire, pp. 78-84.

5 House of Commons Parliamentary Papers Online (1865) Correspondence Respecting Protestant Missionaries and Converts in Turkey Presented to Both Houses of Parliament by Command of Her Majesty. London: Harrison and sons, 1865. Retrieved May 21, 2015, from www.parlipapers.chad wyck.co.uk.

6 J. Richter, A History of Missions in the Near East, pp. 172-173.

7 S. Cobb, The Real Turk, p. 146.

8 J. Richter, A History of Missions in the Near East, p. 171.

9 H. H. Jessup, The Greek Church and Protestant Missions or Missions to the Oriental Churches, p. 6.

10 A. Rufus, History of the Missions of the American Board of Commissioners for Foreign Missions to the Oriental Churches (Vol. I), pp. 96-97.

11 V. Artinian, Osmanlı Devleti'nde Ermeni Anayasası'nın Doğuşu: 18391863 , p. 55.

12 An Answer to the Charges of the Greek Ecclesiastical Committee at Smyrna against the English and American Missionaries, pp. 11-19.

13 Kyriakos Hatzi Nikolaou Lamprylos (1810-1883) was a publisher promoting the Orthodox resistance against the missionaries in Smyrna. He 


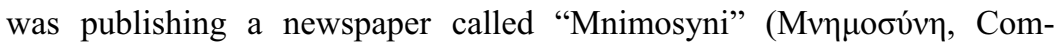

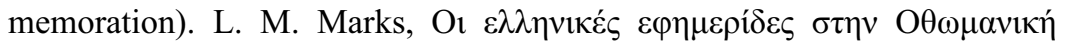

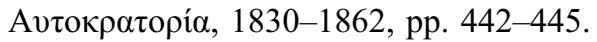

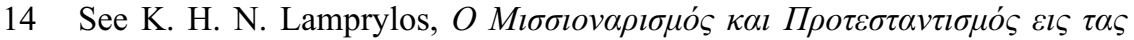

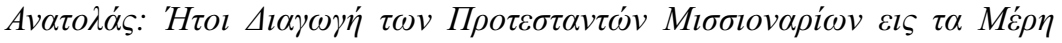

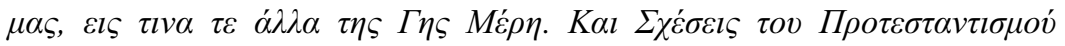

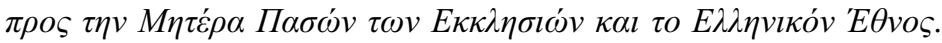

15 C. Şişman, Failed Proselytizers or Modernizers? Protestant Missionaries among the Jews and Sabbateans/Dönmes in the Nineteenth-century Ottoman Empire, pp. 939-940.

16 Turkish Missions. (1884). The Missionary Herald, 426; Central Turkey Mission: The Revival at Adana. (1884). The Missionary Herald, 317.

17 Western Turkey Mission: Church Organized in Gemerek. (January 1904). The Missionary Herald, 28.

18 Letters from the Missions: Western Turkey mission: Joy at Ordoo. (May 1899). The Missionary Herald, 194.

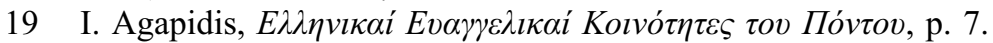

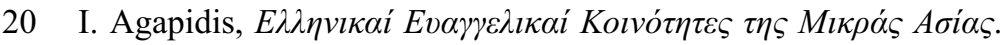

21 H. Özsoy, Kayseri'de Amerikan Misyoner Faaliyetleri ve Talas Amerikan Koleji, p. 36.

22 G. Sabra, Orthodox-Protestant Relations: A View from the Middle East, p. 373.

23 For Maronite opposition to missionaries and for the curious case of an Arab reformer (and a convert), see U. Makdisi, Artillery of Heaven.

24 G. Sabra, Orthodox-Protestant Relations: A View from the Middle East, p. 374.

25 J. B. White, Observations on Heresy and Orthodoxy, p. 5.

26 G. R. Evans, A Brief History of Heresy, p. 159.

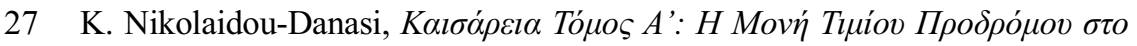

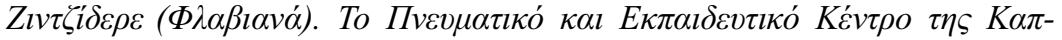

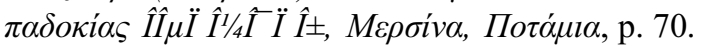

28 For the debates about the need to conduct religious services in Turkish, see S. Benlisoy, "Anatol Ahali-i Rumiyesi," Misyonerler ve Türkçe İbadet Meselesi.

29 Orthodoksia'nın Muhafazası. (February 12-14, 1894). Anatoli, 47734774.

30 E. Gazi, Revisiting Religion and Nationalism in Nineteenth-Century Greece, p. 99.

31 E. Riggs, Anatolia College, Western Turkey, p. 417.

32 G. L. Richards, Are Foreign Missions Worth While? p. 417.

33 Anatolia College was established in Merzifon in September 1886 and was sponsored by the Boston based ABCFM. The majority of the students were Armenians and Greeks with a few Russians and Bulgarians; the Muslim Turks were not officially allowed in foreign schools. 
34 Anatolia was ordered closed in 1916 and most of the Americans left for the U.S. At the time the campus was turned into a Turkish Army Hospital. After the armistice in 1918, the campus became an American run orphanage. J. O. Iatrides, Missionary Educators and the Asia Minor disaster: Anatolia College's Move to Greece, p. 146. In 1924, after the Exchange of Populations between Greece and Turkey, Anatolia College was transferred to Thessaloniki, Greece (See https://anatolia.edu.gr/el/).

35 J. O. Iatrides, Missionary Educators and the Asia Minor Disaster: Anatolia College's Move to Greece, p. 145.

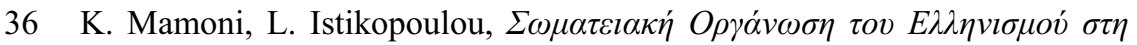

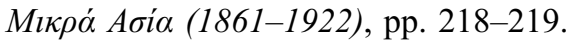

37 E. Gazi, Revisiting Religion and Nationalism in Nineteenth-Century Greece, pp. 100-101.

38 S. Benlisoy, Education in the Turcophone Orthodox Communities of Anatolia during the Nineteenth Century, p. 256.

39 Anatoli, August 14, 1851, 30.

40 Anatoli, February 14, 1853, 104.

41 Anatoli, June 11, 1863, 638.

42 Mezhebe Tereddüt. (30 Iouliou 1888). Terakki, 6.

43 S. Benlisoy, Education in the Turcophone Orthodox Communities of Anatolia During the Nineteenth Century, pp. 267-268, 175.

44 Translation of the firman granted by Sultan Abd-ul Mejeed to his Protestant subjects. (1853). Journal of the American Oriental Society, 4, pp. 443-444. For the principal charter of Protestant community [Protestan Cemaati Nizamname-i Esasiyesi], see V. Artinian, Osmanll Devleti'nde Ermeni Anayasası'nın Doğuşu: 1839-1863.

45 E. Kleovoulos Mektupları. (August 31, 1888). Terakki, 8.

46 E. Kleovoulos Mektuplar1. (September 15, 1888). Terakki, 9.

47 E. Kleovoulos Mektuplar1. (September 30, 1888). Terakki, 10.

48 Ç. L. Çelebi, Socio-economic Relations between Christian and Muslim Communities in the Sanjak of Kayseri in 1870-1880, p. 319.

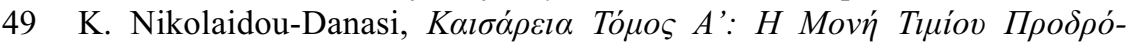

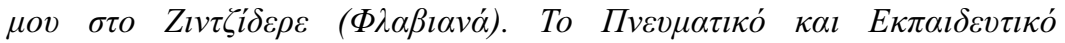

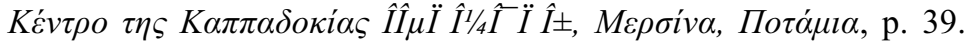

50 See J. Richter, A History of Missions in the Near East, p. 165.

51 U. Makdisi, Artillery of Heaven: American Missionaries and the Failed Conversion of the Middle East, p. 184.

52 E. Gazi, Revisiting Religion and Nationalism in Nineteenth-Century Greece, p. 99.

53 R. Clogg, Some Protestant Tracts Printed at the Press of the Ecumenical Patriarchate in Constantinople: 1818-1820, pp. 163-164.

54 H. S. Barnum, Periodical Literature from the Mission Press, p. 438.

55 J. K. Greene, The Jubilee of “Avedaper," p. 172.

56 Angeliaforos, May 7, 1904, 19.

57 U. Kocabaşoğlu, Anadolu'daki Amerika, pp. 21-22. 
58 E. Gazi, Revisiting Religion and Nationalism in Nineteenth-Century Greece, p. 101.

59 G. Augustinos, "Englightened" Christians and the "Oriental" Churches: Protestant Missions to the Greeks in Asia Minor: 1820-1860, pp. 139140.

60 U. Kocabaşoğlu, Anadolu'daki Amerika, p. 125.

61 O. H. Dwight, The Publication Department of the Western Turkey Mission, p. 52.

62 Angeliaforos, January 5, 1889, 1.

63 Angeliaforos, June 29, 1889, 26.

64 See Y. Bağçeci, Osmanlı Devleti'nde Gregorian Ermenilerle Protestan Ermeniler Arasındaki İlişkiler.

65 Angeliaforos, March 2, 1889, 9.

66 C. Hamlin, My Life and Times, p. 140.

67 G. Augustinos, "Enlightened" Christians and the "Oriental" Churches: Protestant Missions to the Greeks in Asia Minor: 1820-1860, p. 140.

68 Angeliaforos, September 6, 1890, 36.

69 Letters from the Missions: Western Turkey Mission: Joy at Ordoo. (May 1899). The Missionary Herald, p. 195.

70 A Greek Protestant. (1856). The Missionary Herald, p. 291.

71 Western Turkey Mission: Smyrna: the Greek Work. (April 1886). The Missionary Herald, p. 146.

72 An American Oasis. (June 1902). The Missionary Herald, pp. 407-409.

73 A Typical Greek Village. (August 1904).The Missionary Herald, pp. 319323.

74 Angeliaforos, January 30, 1830, 5.

75 Western Turkey Mission: A Visit to Ordu. (1886). The Missionary Herald, p. 219.

76 Angeliaforos, April 13, 1889, 15.

77 Angeliaforos, March 2, 1889, 9.

78 Angeliaforos, July 27, 1889, 30.

79 Angeliaforos, August 3, 1889, 31.

80 Angeliaforos, January 9, 1890, 2.

81 Angeliaforos, October 4, 1890, 40.

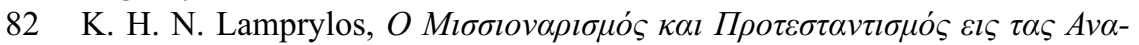

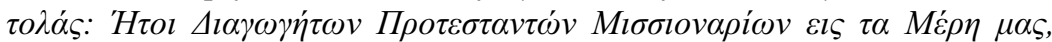

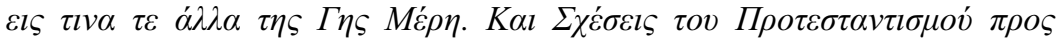

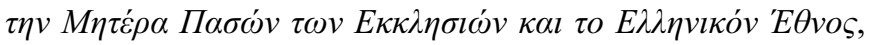

83 As a defense against the missionary schools, these girls' schools were supported by the Philekpaideutiki Etaireia and named after Apostolos Arsakis. See P. Thanailaki, The American Protestant Missionary Schools in Greece in the Nineteenth Century and Greek Orthodox Education, p. 76.

84 CAMS, Cappadocia, Zincidere, Viktoria Seirinidou.

85 L. S. Crawford, For the Younger People: Trebizond and its People, p. 880. 
86 CAMS, Cappadocia, Zincidere, Eleni Serafeimidou.

87 CAMS, Cappadocia, Zincidere, Nikolaos Haritonidis.

88 G. Sabra, Orthodox-Protestant Relations: A View from the Middle East, p. 373.

89 Personal communication with a family member.

90 P. S. Ladas, The Exchange of Minorities: Bulgaria, Greece and Turkey, p. 384.

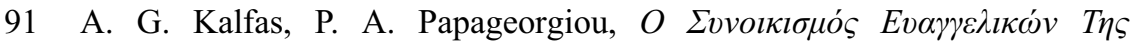

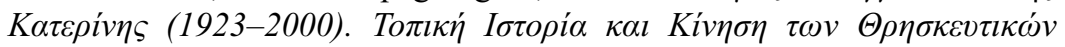

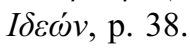

92 Compared to other Western powers, the US gave citizenship status to Ottoman Christians the most. Ortayli claims that missionaries raised citizens for their country in missionary schools. İ. Ortaylı, Osmanlı İmparatorluğu'nda Amerikan Okulları Üzerine Bazı Gözlemler, p. 91.

93 CAMS manuscripts, Cappadocia, Gürümce, Georgios Karaoglanidis, 1958.

94 Interview with Sofia Kosmoglou, May 17, 2013.

95 Interview with Paris A. Papageorgiou, January 28, 2014.

96 CAMS, Cappadocia, Zincidere, Nikolaos Haritonidis.

97 A small group of Greek Catholics remained in Turkey. According to documents from the Vatican there were only 45 in 1998. The last priest of the Greek congregation, Thomas Varsamis, died in 1996. The remaining Greek Catholics currently do not have a separate church and they attend the services of Latin Churches. E. Macar, İstanbul'un Yok Olmuss İki Cemaati: Doğu Ritli Katolik Rumlar ve Bulgarlar.

98 "Prosorinon Politeuma tes Hellados," The Epidaurus Constitution, 1822.

99 There was a small Catholic community nurtured by Venetian authorities in the Ionian Islands. Adding to that, there were Latin Christian Communities on the islands of the Aegean Sea: Naxos, Tinos, Siros and Thira of the Cyclades and on the island of Chios. During the Greek Revolution, the Catholics on the islands held back since they had already been enjoying some degree of autonomy and freedom under the Ottoman rule. For Frazee, they did not see the future of the revolution and wanted conserve their existing position. For this reason they were insulted of being "Turk-worshippers." C. A. Frazee, The Greek Catholic Islanders and the Revolution of 1821, pp. 315, 320-321.

100 In the age of nationalism, religion seems to be the main marker of nationality in the Balkans. For this reason in Bulgaria as well, the activities of the Protestants were faced suspiciously and were thought to destroy the national unity which was based on the Orthodox faith. See L. J. Budilová, M. Jakoubek, Bulgarian Protestants and the Czech Village of Voyvodovo, pp. 28, 33.

\section{Chapter 6}

1 I have to give credit to my friend Anastas Vangeli. 


\section{Bibliography}

\section{Archives and Libraries}

\section{Greece}

Centre for Asia Minor Studies.

Oral Tradition Archives of the Centre for Asia Minor Studies (CAMS).

Photography Archive of the Centre for Asia Minor Studies (CAMS).

Greek Historical Evangelical Archive.

The Gennadius Library.

\section{Turkey}

National Library of Turkey.

\section{Newspapers and periodicals}

Anatoli 1851-1854; 1891-1897.

Terakki 1888.

Angeliaforos 1889-1890; 1903-1904.

The Missionary Herald 1870-1922.

\section{Almanacs and Regulations of Brotherhood Organizations}

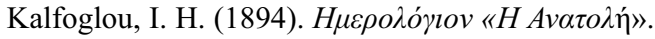

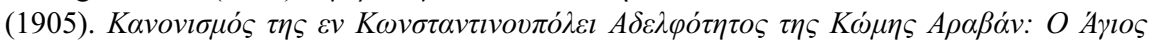

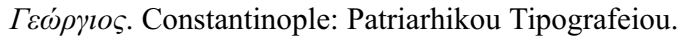

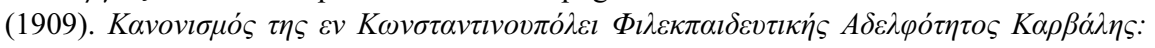

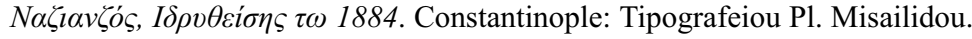

\section{Books and Articles}

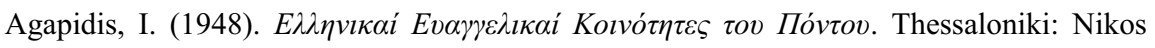
Z. Zlatanos Publication House.

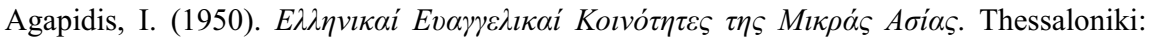
Nikos Z. Zlatanos Publication House.

Ahladi, E. (2008). Izmir'de Ittihatçllar ve Rumlar: Yunan-Rum Boykotu (1908-1911). Kebikeç, 26, 188-190. 
Aktar, A. (2007). Debating the Armenian Massacres in the Last Ottoman Parliament, November-December 1918. History Workshop Journal, 64(64), 240-270.

Aleksov, B. (2005). Perception of Islamization in the Serbian National Discourse. Southeast European and Black Sea Studies, 5(1), 113-127.

Alpan, A. S. (2013). But the Memory Remains: History, Memory and the 1923 Greco-Turkish Population Exchange. The Historical Review/La Revue Historique, 9, 199-232.

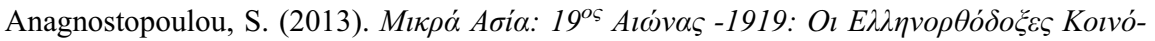

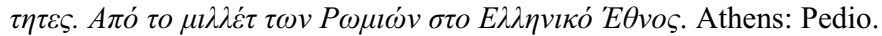

Anderson, B. (2006). Imagined Communities: Reflections on the Origin and Spread of Nationalism. New York, NY; London: Verso.

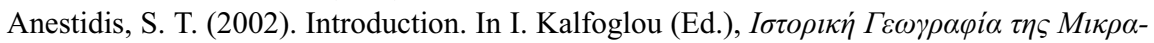

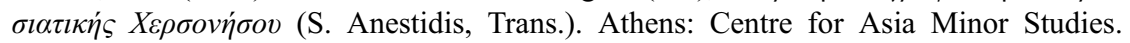
(Original work published 1899), pp. 13-34.

Anestidis, S. T. (2014). Yunan ve Türk Edebiyatında Erken Karamanlı Tiplemeleri. In E. Balta (Ed.), Cultural Encounters in the Turkish-speaking Communities of the Late Ottoman Empire (pp. 29-40). Istanbul: The Isis Press.

Anhegger, R. (2001). Evangelinos Misailidis ve Türkçe Konuşan Dindaşları. Tarih ve Toplum, XXXV(209), 11-18.

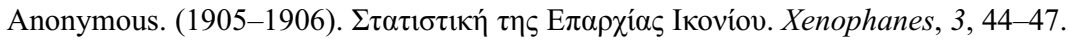

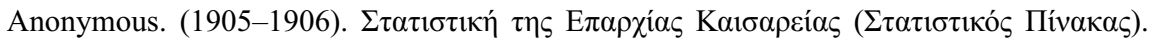
Xenophanes, 3, 230-233.

(1836). An Answer to the Charges of the Greek Ecclesiastical Committee at Smyrna against the English and American Missionaries. Smyrna: Harlow American Press.

Arendt, H. (1998). The Human Condition. Chicago, IL: University of Chicago Press.

Artinian, V. (2004). Osmanl Devleti'nde Ermeni Anayasası'nın Doğuşu: 1839-1863. Istanbul: Aras Yayıncilik.

Augustinos, G. (1986). "Englightened" Christians and the "Oriental" Churches: Protestant Missions to the Greeks in Asia Minor: 1820-1860. Journal of Modern Greek Studies, 4 (2), 129-142.

Augustinos, G. (1992). The Greeks of Asia Minor: Confession, Community, and Ethnicity in the Nineteenth Century. Kent, $\mathrm{OH}$ : Kent State University Press.

Baer, M. D. (2008). Honored by the Glory of Islam: Conversion and Conquest in Ottoman Europe. Oxford: Oxford University Press.

Bağçeci, Y. (2008). Osmanlı Devleti'nde Gregorian Ermenilerle Protestan Ermeniler Arasındaki İlişkiler. Turkish Studies, 3(7), 169-192.

Balta, E. (1987a). Karamanlidika: Additions (1584-1900): Bibliographie Analytique. Athenes: Centre D'Études De'Asie Mineure.

Balta, E. (1987b). Karamanlidika: Nouvelles Additions et Complements I. Athenes: Centre D'Études De'Asie Mineure.

Balta, E. (1990). Karamanlıca Kitapların Önsözleri. Tarih ve Toplum, 74, 18-20.

Balta, E. (1997). Karamanlidika: XXE Siècle: Bibliographie Analytiqu. Athenes: Centre D’Études De'Asie Mineure.

Balta, E. (2003). Gerçi Rum isek de Rumca Bilmez Türkçe Söyleriz: The Adventure of an Identity in the Triptych: Vatan, Religion and Language. Türk Kültürü Incelemeleri Dergisi, 8, 25-44.

Balta, E. (2010). Karamanli Press Smyrna 1845- Athens 1926. In Beyond the Language Frontier. Studies on the Karamanlis and the Karamanlidika Printing. Analecta Isisiana CX, Istanbul: The Isis Press, pp. 107-122. 
Balta, E. \& Kappler, M. (Eds.). (2010). Cries and Whispers in Karamanlidika Books. Wiesbaden: Harrassowitz Verlag.

Bardakjian, K. B. (1982). The Rise of the Armenian Patriarchate of Constantinople. In B. Braude \& B. Lewis (Eds.), Christians and Jews in the Ottoman Empire (Vol. 1). New York, NY: Holmes and Meier Publishers, pp. 87-98.

Barkey, K. (2008). Empire of Difference: The Ottomans in Comparative Perspective. New York, NY: Cambridge University Press.

Barnum, H. S. (1903). Periodical Literature from the Mission Press. The Missionary Herald, 15, 436-439.

Barth, F. (1969). Introduction. In F. Barth (Ed.), Ethnic Groups and Boundaries: The Social Organization of Culture Difference. Boston, MA: Little, Brown and Company, pp. 9-38.

Benhabib, S. (1997). The Embattled Public Sphere: Hannah Arendt, Juergen Habermas and Beyond. Theoria, 90(1), 1-24.

Benlisoy, F. \& Benlisoy, S. (2000). 19. Yüzyılda Karamanlılar ve Eğitim: Nevşehir Mektepleri. Toplumsal Tarih, 74, 24-33.

Benlisoy, F. \& Benlisoy, S. (2010). "Karamanlılar," “Anadolu Ahalisi” ve "Aşağı Tabakalar": Türkdilli Anadolu Ortodokslarında Kimlik Algısı. Tarih ve Toplum Yeni Yaklaşımlar, 11, 7-22.

Benlisoy, F. \& Benlisoy, S. (2016). Türk Milliyetçiliğinde Katedilmemiş bir Yol: "Hıristiyan Türkler" ve Papa Eftim. İstanbul: İstos.

Benlisoy, S. (2003a). İstanbul'a Göçmüş Ürgüplü Ortodoksların Kurduğu Bir Cemiyet: “Areti” Maarifperveran Cemiyeti. Tarih Ve Toplum, 233, 4-9.

Benlisoy, S. (2003b). İstanbul'da Yaşayan Nevşehirli Ortodokslar Tarafından Kurulan Papa Yeorgios Nam Cemiyet-i Islahiyyesi. Tarih ve Toplum, 236, 35-41.

Benlisoy, S. (2010). Education in the Turcophone Orthodox Communities of Anatolia during the Nineteenth Century (Unpublished Doctoral Dissertation, Boğaziçi University).

Benlisoy, S. (2019). “Anatol Ahali-i Rumiyesi,” Misyonerler ve Türkçe İbadet Meselesi. Toplumsal Tarih, 306, 28-34.

Ben-Naeh, Y. (2009). Sultanlar Diyarında Yahudiler: 17. yüzyılda Osmanl Yahudi Toplumu. Istanbul: Goa Basım Yayın.

Bjørnlund, M. (2008). The 1914 Cleansing of Aegean Greeks. Journal of Genocide Research, 10(1), 41-57.

Bosworth, C. E. (1982). The Concept of Dhimma in Early Islam. In B. Braude \& B. Lewis (Eds.), Christians and Jews in the Ottoman Empire (Vol. 1). New York, NY: Holmes and Meier Publishers, pp. 37-54.

Boura, C. (1999). The Greek Millet in Turkish Politics: Greeks in the Ottoman Parliament (1908-1918). In D. Gondicas \& C. Issawi (Eds.), Ottoman Greeks in the Age of Nationalism. New Jersey: The Darwin Press, pp. 193-206.

Bowman, G. (2002). Comment on R. Hayden, Antagonistic Tolerance: Competitive Sharing of Religious Sites in South Asia and the Balkans. Current Anthropology, 43(2), 219-220.

Braude, B. (1982). Foundation Myths of the Millet System. In B. Braude \& B. Lewis (Eds.), Christians and Jews in the Ottoman Empire (Vol. 1). New York, NY: Holmes and Meier Publishers, pp. 69-88.

Bringa, T. (1995). Being a Muslim the Bosnian Way: Identity and Community in a Central Bosnian Village. Princeton, NJ: Princeton University Press.

Brown, W. (2006). Regulating Aversion: Tolerance in the Age of Identity and Empire. Princeton, NJ and Oxford: Princeton University Press. 
Budilová, L. J. \& Jakoubek, M. (2017). Bulgarian Protestants and the Chech Village of Voyvodovo. Sofia: New Bulgarian University.

Cahen, C. D. (2012). Dhimma. In P. Bearman, T. Bianquis, C.E. Bosworth, E. van Donzel \& W.P. Heinrichs (Eds.), Encyclopedia of Islam Second Edition. Leiden: Brill, pp. 227-231, Online Publication.

Campos, M. (2011). Ottoman Brothers: Muslims, Christians, and Jews in Early TwentiethCentury Palestine. Stanford, CA: Stanford University Press.

Carter, I. (2013). Are Toleration and Respect Compatible? Journal of Applied Philosophy, 30(3), 195-208.

Caunce, S. (2011). Sözlü Tarih Ve Yerel Tarihçi. Istanbul: Tarih Vakfı Yurt Yayınları.

Çelebi, Ç. L. (2009). Socio-economic Relations between Christian and Muslim Communities in the Sanjak of Kayseri in 1870-1880 (Unpublished Doctoral dissertation, National and Kapodistrian University of Athens).

Çetinkaya, Y. D. (2014). The Young Turks and the Boycott Movement: Nationalism, Protest and the Working Classes in the Formation of Modern Turkey. London; New York, NY: I. B. Tauris.

Clogg, R. (1968). Some Protestant Tracts Printed at the Press of the Ecumenical Patriarchate in Constantinople: 1818-1820. Eastern Churches Review, 2(2), 152-164.

Clogg, R. (1978). Some Karamanlidika Inscriptions from the Monastery of the Zoodokhos Pigi, Balıkl1. Byzantine and Modern Greek Studies, 4, 55-67.

Clogg, R. (1982). The Greek Millet in the Ottoman Empire. In B. Braude \& B. Lewis (Eds.), Christians and Jews in the Ottoman Empire: The Functioning of a Plural Society (Vol. 1). New York, NY: Holmes \& Meier Publishers, pp. 185-207.

Clogg, R. (1996). Anadolu Hıristiyan Karındaşlarımız: The Turkish-Speaking Greeks of Asia Minor. Anatolica: Studies in the Greek East in the $18^{\text {th }}$ and $19^{\text {th }}$ Centuries. Hampshire; Vermont: Variorum, pp. 65-91.

Clogg, R. (1999). A Millet within a Millet: The Karamanlides. In D. Gondicas \& C. Issawi (Eds.), Ottoman Greeks in the Age of Nationalism. New Jersey: The Darwin Press, pp. $115-132$.

Cobb, S. (1914). The Real Turk. Boston, MA; New York, NY; Chicago, IL: The Pilgrim Press.

Cohen, A. (2004). What Toleration Is. Ethics, 115(1), 68-95.

Crawford, L. S. (1906). For the Younger People: Trebizond and its People. The Missionary Herald.

Daniel, E. L. (2012). Manicheanism. In T.B. Bearman, C.E. Bosworth, E. van Donzel, W. P. Heinrichs (Eds.), Encyclopedia of Islam Second Edition. Leiden: Brill, pp. 428-429.

Davison, R. H. (1982). The Millets as Agents of Change in the Nineteenth-Century Ottoman Empire. In B. Braude \& B. Lewis (Eds.), Christians and Jews in the Ottoman Empire (Vol. 1). New York, NY: Holmes and Meier Publishers, pp. 187-208.

Dawkins, R. (1916). Modern Greek in Asia Minor: A Study of the Dialects of Silli, Cappadocia and Pharasa with Grammer, Texts, Translations and Glossary. Cambridge: Cambridge University Press.

Dean, M. (1999). Governmentality: Power and Rule in Modern Society. Thousand Oaks, CA: Sage Publications.

Deringil, S. (2000). There is No Compulsion in Religion: Conversion and Apostasy in the Late Ottoman Empire 1839-1856. Comparative Studies in Society and History, 40, $547-575$.

Deringil, S. (2012). Conversion and Apostasy in the Late Ottoman Empire. New York, NY: Cambridge University Press. 
Doumanis, N. (2013). Before the Nation: Muslim-Christian Co-existence and its Destruction in Late Ottoman Anatolia. Oxford: Oxford University Press.

Dwight, O. H. (1898). The Publication Department of the Western Turkey Mission. The Missionary Herald.

Dyke, V. V. (1985). Human Rights, Ethnicity, and Discrimination. London: Greenwood press.

Ekmečić, M. (1989). Stvaranje Jugoslavije 1790-1818. Belgrade: Prosteva.

Eldem, E. (1999). Istanbul: From Imperial to Peripheralized Capital. In E. Eldem, D. Goffman \& B. Masters (Eds.), The Ottoman City between East and West. New York, NY: Cambridge University Press, pp. 135-206.

Emmanuilidis, E. (2014). Osmanlı İmparatorluğunun Son Yılları. Istanbul: Belge Yayınları. (Orijinal work published 1924).

Epstein, M. A. (1982). The Leadership of the Ottoman Jews in the Fifteenth and Sixteenth Centuries. In B. Braude \& B. Lewis (Eds.), Christians and Jews in the Ottoman Empire (Vol. 1). New York, NY: Holmes and Meier Publishers, pp. 101-115.

Erdem, H. (2005). "Do Not Think of the Greeks as Agricultural Laborers": Ottoman Responses to the Greek War of Independence. In F. Birtek \& T. Dragonas (Eds.), Citizenship and Nation-State in Greece and Turkey. Oxon; New York, NY: Routledge, pp. $67-84$.

Ergene, T. (1951). Istiklal Harbinde Türk Ortodoksları. Istanbul: İ. P. Neşriyat Servisi.

Erol, M. (2004). Evangelinos Misailidis. Toplumsal Tarih, 128, 70-71.

Erol, M. (2014). Cultural Manifestations of a Symbiosis: Karamanlidika Epitaphs of the Nineteenth Century. In E. Balta (Ed.), Cultural Encounters in the Turkish-Speaking Communities of the Late Ottoman Empire. Proceedings of the III International Workshop of Karamanlidika Studies. İstanbul: Isis Press, pp. 77-104.

Ertuğrul, H. (1998). Azınlık ve Yabancı Okullarının Türk Toplumuna Etkisi. Istanbul: Nesil Yayınları.

Evans, G. R. (2008). A Brief History of Heresy. Hoboken: Wiley.

Exertzoglou, H. (1999). The Development of a Greek Ottoman Bourgeoisie: Investment Patterns in the Ottoman Empire, 1850-1914. In D. Gondicas \& C. Issawi (Eds.), Ottoman Greeks in the Age of Nationalism. New Jersey: The Darwin Press, pp. 89-114.

Foucault, M. (1991). Governmentality. In A. Burchell, C. Gordon \& P. Miller (Eds.), The Foucault Effect: Studies in Governmentality with Two Lectures by and an Interview with Michel Foucault. Chicago, IL: The University of Chicago Press, pp. 87-104.

Frazee, C. A. (1979). The Greek Catholic Islanders and the Revolution of 1821. East European Quarterly, 13(3), 315-326.

Friedmann, Y. (2003). Tolerance and Coercion in Islam: Interfaith Relations in the Muslim Tradition. New York, NY: Cambridge University Press.

Gazi, E. (2009). Revisiting Religion and Nationalism in Nineteenth-Century Greece. In R. Beaton \& D. Ricks (Eds.), The Making of Modern Greece. Surrey: Ashgate, pp. 95-106.

Gellner, E. (1983). Nations and Nationalism. Oxford: Basil Blackwell.

Georgelin, H. (2012). Armenian Inter-community Relations in Late Ottoman Smyrna. In R. G. Hovannisian (Ed.), Armenian Smyrna/Izmir: The Aegean Communities. Costa Mesa: Mazda Publishers, pp. 177-190.

Gingeras, R. (2009). Sorrowful Shores: Violence, Ethnicity, and the End of the Ottoman Empire, 1912-1923. New York, NY: Oxford University Press. 
Goffman, D. (1999). Izmir: From Village to Colonial Port City. In E. Eldem, D. Goffman \& B. Masters (Eds.), The Ottoman City between East and West. New York, NY: Cambridge University Press, pp. 79-134.

Göktürk, G. (2017). Zalim Gurbet Sana Yol Vermiyor mu? Geride Kalan Ortodoks Kadınların Gözünden Gurbetliğe Bakış. Toplum ve Bilim, 141, 122-140.

Greene, J. K. (1905). The Jubilee of “Avedaper.” The Missionary Herald.

Grigoriadis, I. N. (2013). Instilling Religion in Greek and Turkish Nationalism: A "Sacred Synthesis". New York, NY: Palgrave Macmillan.

Gülsoy, U. (2010). Cizyeden Vatandaşlı̆̆a: Osmanlı'nın Gayrimüslim Askerleri. İstanbul: Timaş Yayınları.

Gutmann, A. (2004). Identity in Democracy. Princeton, NJ: Princeton University Press.

Hacısalihoğlu, M. (2007). Osmanlı İmparatorluğunda Zorunlu Askerlik Sistemine Geçiş: Ordu-Millet Düşüncesi. Toplumsal Tarih, 164, 58-64.

Hamlin, C. (1893). My Life and Times. New York, NY; Chicago, IL; Toronto: Fleming H. Revell Company (Publishers of Evangelical Literature).

Hanley, W. (2008). Grieving Cosmopolitanism in Middle East Studies. History Compass, 6(5), 1346-1367.

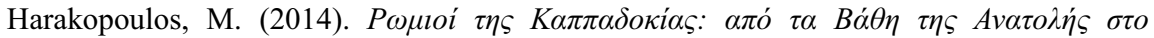

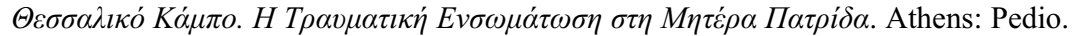

Hasluck, F. W. (1929). Christianity and Islam under the Sultans. Oxford: Clarendon Press.

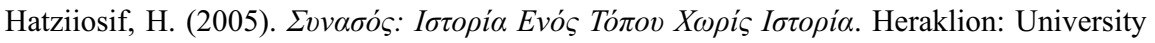
Press of Crete.

Haydaroğlu, I. P. (1990). Osmanlı Imparatorluğunda Yabancı Okullar. Ankara: Kültür Bakanlığı.

Hayden, R. M. (2002). Antagonistic Tolerance: Competitive Sharing of Religious Sites in South Asia and the Balkans. Current Anthropology, 43(2), 205-231.

Hayden, R. M. (Ed.). (2016). Antagonistic Tolerance: Competitive Sharing of Religious Sites and Spaces. Oxon; New York, NY: Routledge.

Hayden, R. M. \& Naumovic, S. (2013). Imagined Commonalities: The Invention of a Late Ottoman "Tradition" of Coexistence. American Anthropologist, 115(2), 324-334.

Hayden, R. M., Sözer, H., Tanyeri-Erdemir, T. \& Erdemir, A. (2011). The Byzantine Mosque at Trilye: A Processual Analysis of Dominance, Sharing, Transformation and Tolerance. History and Anthropology, 22(1), 1-17.

Hirschon, R. (1998). Heirs of the Greek Catastrophe: The Social Life of Asia Minor Refugees in Piraeus. New York, NY; Oxford: Berghahn Books.

Hirschon, R. (2006). Knowledge of Diversity: Towards a More Differentiated Set of "Greek" Perceptions of "Turks." South European Society and Politics, 11(1), 61-78.

Hobsbawm, E. (1992). Nations and Nationalism Since 1780: Programme, Myth, Reality. Cambridge; New York, NY: Cambridge University Press.

Huntington, S. P. (1997). The Clash of Civilizations and the Remaking of World Order ( $1^{\text {st }}$ Touchstone ed.). New York, NY: Touchstone.

Iatrides, J. O. (1986). Missionary Educators and the Asia Minor Disaster: Anatolia College's Move to Greece. Journal of Modern Greek Studies, 4(2), 143-157.

Iğsı, A. (2008). Documenting the past and Publicizing Personal Stories: Sensescapes and the 1923 Greco-Turkish Population Exchange in Contemporary Turkey. Journal of Modern Greek Studies, 26, 451-487.

Iğsı, A. (2018). Humanism in Ruins. Stanford, CA: Stanford University Press.

İnalcık, H. (1991). The Status of the Greek Orthodox Patriarch under the Ottomans. Turcica, XI-XII, 195-219. 
Jessup, H. H. (1891). The Greek Church and Protestant Missions or Missions to the Oriental Churches. New York, NY: Christian Literature Co.

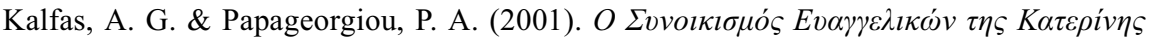

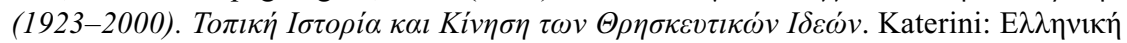

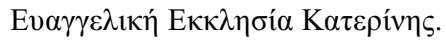

Kamouzis, D. (2013). Elites and the Formation of National Identity. In B. C. Fortna, S. Katsikas, D. Kamouzis \& P. Konortas (Eds.), State-nationalisms in the Ottoman Empire, Greece and Turkey: Orthodox and Muslims, 1830-1945. London; New York, NY: Routledge, pp. 13-46.

Kapoli, E. (2008). Archive of Oral Tradition of the Centre for Asia Minor Studies: Its Formation and its Contribution to Research. Ateliers d'anthropologie, 32. Retrieved March 22, 2020, from http://journals.openedition.org/ateliers/1143.

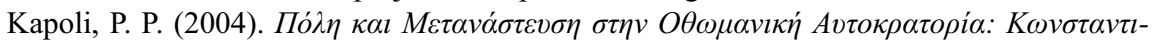
voí $\pi о \lambda \eta \kappa \alpha l ~ K \alpha \pi \pi \alpha \delta o ́ \kappa \varepsilon \varsigma ~ M \varepsilon \tau \alpha v \alpha ́ \sigma \tau \varepsilon \varsigma$ (1856-1908). (Unpublished MA thesis, National and Kapodistrian University of Athens, 2004).

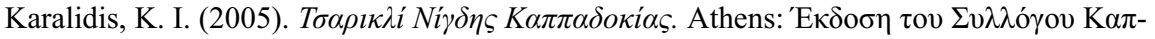

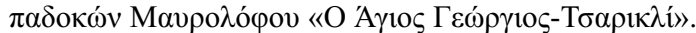

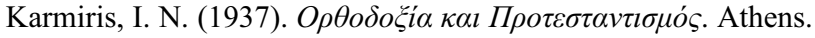

Kazamias, A. (1991). The Education of the Greeks in the Ottoman Empire, 1876-1923: A Case Study of Controlled Toleration. In J. J. Tomiak (Ed.), Schooling, Educational Policy and Ethnic Identity. New York, NY: New York University Press, pp. 343-367.

Kechriotis, V. (2014). Osmanlı İmparatorluğu'nun Son Döneminde Karamanlı Rum Ortodoks Diasporası: İzmir Mebusu Emmanouil Emmanouilidis. Toplumsal Tarih, 251, $38-43$.

Kechriotis, V. (2015a). Ottomanism with a Greek Face: Karamanli Greek Orthodox Diaspora at the End of the Ottoman Empire. In M. Isabella \& K. Zanou (Eds.), Mediterranean Diasporas: Politics and Ideology in the Long $19^{\text {th }}$ century. London: Bloomsbury, pp. 189-204.

Kechriotis, V. (2015b). Atina'da Kapadokyalı, İzmir'de Atinalı, İstanbul'a Mebus: Pavlos Karolidis'in Farklı Kişilik ve Aidiyetleri. Toplumsal Tarih, 257, 28-35.

King, P. (1998). Toleration. London: Frank Cass Publishers.

Kirtsoglou, E. \& Sistani, L. (2003). The Other Then, the Other Now, the Other Within: Stereotypical Images and Narrative Captions of the Turk in Northern and Central Greece. Journal of Mediterranean Studies, 13(2), 189-213.

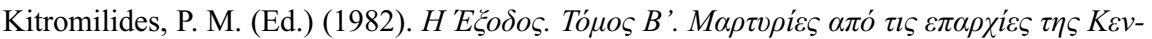

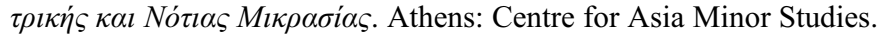

Kitromilides, P. M. (1990). Greek Irredentism in Asia Minor and Cyprus. Middle East Studies, 26(1), 3-17.

Kitromilides, P. M. (1994). Enlightenment, Nationalism and Orthodoxy: Studies in the Culture and Political Thought of Southeastern Europe. Aldershot; Hampshire: Variorum.

Kitromilides, P. M. (2013). Enlightenment and Revolution: The Making of Modern Greece. Cambridge, MA: Harvard University Press.

Kocabaşoğlu, U. (2000). Anadolu'daki Amerika. Ankara: İmge Yayınları.

Kojève, A. (1980). In Place of an Introduction. In A. Bloom (Ed.), Introduction to the Reading of Hegel. Ithaca, NY; London: Cornell University Press, pp. 3-30.

Konortas, P. (1999). From Ta'ife to Millet. In D. Gondicas \& C. Issawi (Eds.), Ottoman Greeks in the Age of Nationalism: Politics, Economy, and Society in the Nineteenth Century. Princeton, NJ: The Darwin Press, pp. 169-180. 
Koraes, A. (1970). Report on the Present State of Civilization in Greece. In E. Kedourie (Ed.), Nationalism in Asia and Africa. New York, NY: World Pub. Co, pp. 153-188.

Kritikos, G. (1999-2000). Motives for the Compulsory Exchange. Deltio: Bulletin of the Centre for Asia Minor Studies, 13, 209-224.

Kritovulos. (2013). Istanbul'un Fethi: Tarih-i Sultan Mehmet Han-ı Sani. İstanbul: Kap1 Yayınları.

Kymlicka, W. (1996). Two Models of Pluralism and Tolerance. In D. Heyd (Ed.), Toleration: An Elusive Virtue. Princeton, NJ: Princeton University Press, pp. 81-105.

Ladas, S. P. (1932). The Exchange of Minorities: Bulgaria, Greece and Turkey. New York, NY: The Macmillan Company, pp. 81-105.

Lafi, N. (2008). The Ottoman Cosmopolitan Hypothesis in the Light of Pheng Cheah's Critical Explorations of Cosmopolitanism. Transnationalism and Colonialism. EUME Summer School. Istanbul.

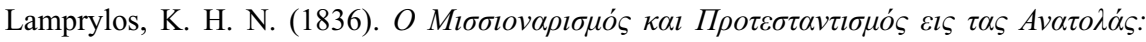

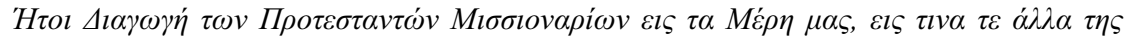

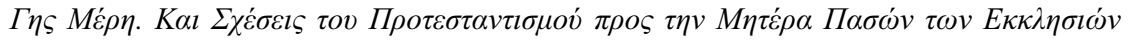

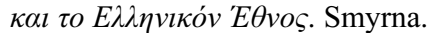

Layoun, M. N. (2001). Wedded to the Land? Gender, Boundaries and Nationalism in Crisis. Durham; London: Duke University Press.

Lessersohn, N. (2015). "Provincial Cosmopolitanism" in Late Ottoman Anatolia: Livanio an Armenian Shoemaker's Memoir. Comparative Studies in Society and History, 57(2), 528-556.

Lewis, B. (2002). The Emergence of Modern Turkey. New York, NY: Oxford University Press.

Liakos, A. (2008). Hellenism and the Making of Modern Greece: Time, Language, Space. In K. Zacharia (Ed.), Hellenisms: Culture, Identity, and Ethnicity from Antiquity to Modernity. Hampshire; Burlington: Ashgate, pp. 201-236.

Livanios, D. (2003). Making Borders, Unmaking Identities: Frontiers and Nationalism in the Balkans, 1774-1913. Seminar Paper Delivered at the Watson Institute for International Studies. Brown University.

Locke, J. (2010). A Letter Concerning Toleration. In R. Vernon (Ed.), Locke on Toleration. Cambridge: Cambridge University Press, pp. 3-46.

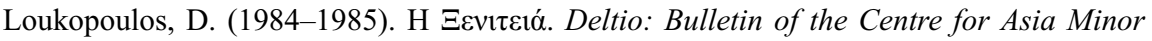
Studies, 5 .

Macar, E. (2006). İstanbul'un Yok olmuş İki Cemaati: Doğu Ritli Katolik Rumlar ve Bulgarlar. Istanbul: İletişim.

Mackridge, P. (2009). Language and National Identity in Greece 1766-1976. New York, NY: Oxford University Press.

Makdisi, U. (2008). Artillery of Heaven: American Missionaries and the Failed Conversion of the Middle East. New York, NY: Cornell University Press.

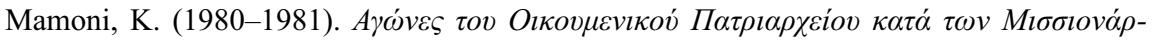

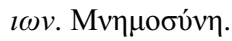

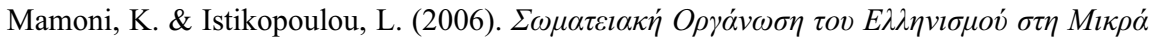

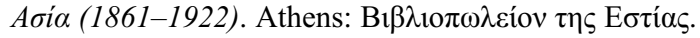

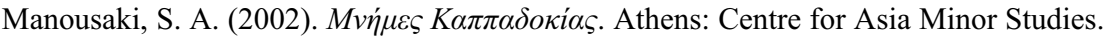

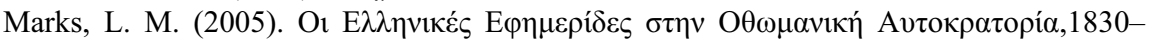

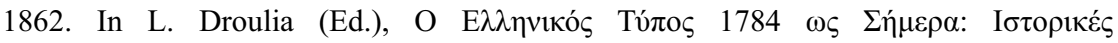

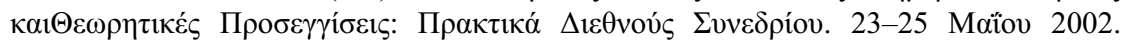

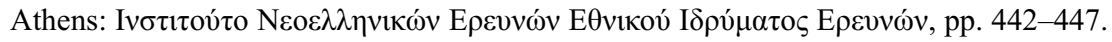


Masters, B. (2001). Christians and Jews in the Ottoman Arab World: The Roots of Sectarianism. New York, NY: Cambridge University Press.

Mazower, M. (2000). The Balkans. New York, NY: Modern Library.

McCarthy, J. (2001). The Ottoman Peoples and the End of Empire. New York, NY: Arnold Publishers.

McKinnon, C. (2006). Toleration: A Critical Introduction. London; New York, NY: Routledge.

Ménage, V. L. (1979). The Islamization of Anatolia. In N. Levtzion (Ed.), Conversion to Islam. New York, NY: Holmes and Meier, pp. 52-67.

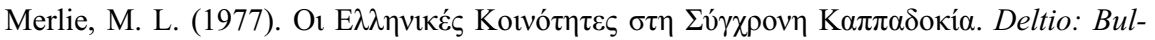
letin of the Centre for Asia Minor Studies, 1.

Mill, J. S. (2009). On Liberty. Auckland, New Zealand: The Floating Press (from a 1909 edition).

Miller, D. (1999). Group Identities, National Identities and Democratic Politics. In J. Horton \& S. Mendus (Eds.), Toleration, Identity and Difference. New York, NY: Palgrave Macmillan, pp. 103-125.

Monk, I. H. (1999). Toleration and Moral Will. In J. Horton \& S. Mendus (Eds.), Toleration, Identity and Difference. New York, NY: Palgrave Macmillan, pp. 17-37.

Mourelos, Y. G. (1985). The 1914 Persecutions and the First Attempt at an Exchange of Minorities Between Greece and Turkey. Balkan Studies, 26(2), 389-413.

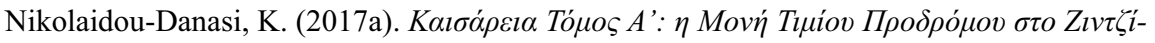

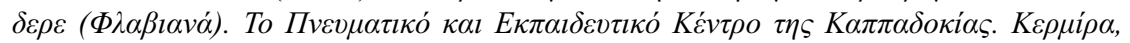

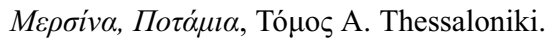

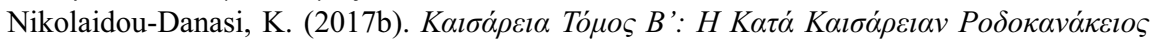

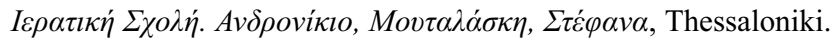

Orakçı, M. (2014). Karamanlıca Bir Gazete: Terakki. In E. Balta (Ed.), Cultural Encounters in the Turkish-speaking Communities of the Late Ottoman Empire. Istanbul: The Isis Press, pp. 411-428.

Ortaylı, İ. (1981). Osmanlı İmparatorluğu'nda Amerikan Okulları Üzerine Bazı Gözlemler. Amme İdaresi Dergisi, 14(3), 87-96.

Ortaylı, İ. (2008). Osmanlı'da Milletler ve Diplomasi. İstanbul: Türkiye İş Bankası Kültür Yayınlar1.

Öz, M. (2013). Zındık. İslam Ansiklopedisi. Diyanet İşleri Başkanlığı. Retrived March 22, 2020, from https://islamansiklopedisi.org.tr/zindik.

Özdemir, E. R. (2006). Borders of Belonging in the "Exchanged" Generations of Karamanlis (Unpublished MA Thesis, Koç University).

Ozil, A. (2013). Orthodox Christians in the Late Ottoman Empire: A Study of Communal Relations in Anatolia. New York, NY: Routledge.

Özkırımlı, U. \& Sofos, S. A. (2008). Tormented by History: Nationalism in Greece and Turkey. London: Hurst Publishers.

Özsoy, H. (1996). Kayseri'de Amerikan Misyoner Faaliyetleri ve Talas Amerikan Koleji. Kayseri: Talas Belediyesi Kültür Yayınları.

Özyürek, E. (2007). The Politics of Public Memory in Turkey. Syracuse; New York, NY: Syracuse University Press.

Papa Efthim. (1925). Papa Efthim Efendi'nin Orthodoxos Ahaliye Müracaatı Ve Patrikhaneye Karşı Müdafaanamesi. Centre for Asia Minor Studies. Karamanlidika book collection.

Papailias, P. (2004). Genres of Recollection: Archival Poetics and Modern Greece: Anthropology, History, and the Critical Imagination. New York, NY: Palgrave Macmillan. 
Parekh, B. (2006). Rethinking Multiculturalism: Cultural Diversity and Political Theory. New York, NY: Palgrave Macmillan.

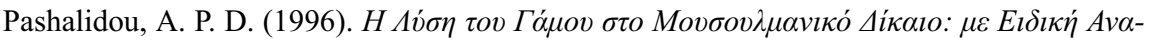

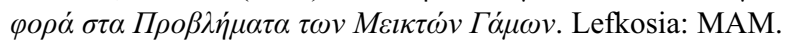

Patsavos, L. J. \& Joanides, C. J. (2000). Interchurch Marriages: An Orthodox Perspective. Greek Orthodox Theological Review, 45(1/4).

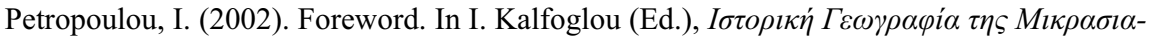

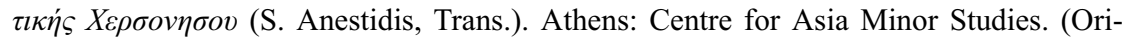
ginal work published 1899).

Philipp, T. (2004). Bilād Al-šām in the Modern Period: Integration into the Ottoman Empire and New Relations with Europe. Arabica, 51(4), 401-418.

Phillips, A. (1999). The Politisation of Difference: Does This Make for a More Intolerant Society? In J. Horton \& S. Mendus (Eds.), Toleration, Identity and Difference. New York, NY: Palgrave Macmillan.

Portelli, A. (2002). What Makes Oral History Different? In R. Perk \& A. Thomson (Eds.), Oral History Reader. New York, NY: Routledge.

Psomiades, H. J. (1960). The Oecumenical Patriarchate under the Turkish Republic: The First Ten Years. Greek Orthodox Theological Review, 6(62), 56-80.

Quataert, D. (1997). Clothing Laws, State, and Society in the Ottoman Empire, 1720-1829. International Journal of Middle East Studies, 29(3), 403-425.

Richards, G. L. (1919). Are Foreign Missions Worth While? The Missionary Herald.

Richter, J. (1910). A History of Missions in the near East. Edinburgh: Oliphant, Anderson \& Ferrier.

Riggs, E. (1886). Anatolia College, Western Turkey. The Missionary Herald.

Roudometof, V. (1998). From Rum Millet to Greek Nation: Enlightenment, Secularization, and National Identity in Ottoman Balkan Society, 1453-1821. Journal of Modern Greek Studies, 16.

Rufus, A. (1873). History of the Missions of the American Board of Commissioners for Foreign Missions to the Oriental Churches (Vol. 1). Boston, MA: Congregational Publishing Society.

Sabra, G. (1999). Orthodox-Protestant Relations: A View from the Middle East. The Ecumenical Review, 51(4), 372-375.

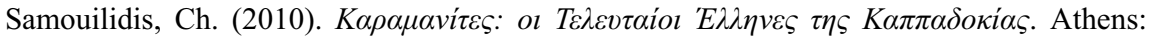
Estia.

Sennett, R. (2004). Respect: The Formation of Character in an Age of Inequality. London: Penguin.

Shaw, S. (1976). History of the Ottoman Empire and Modern Turkey: Empire of the Gazis: The Rise and Decline of the Ottoman Empire, 1280-1808 (Vol. 1). Cambridge, New York, NY: Cambridge University Press.

Sigler, A. J. (1983). Minority Rights: A Comparative Analysis. Connecticut: Greenwood press.

Şimşek, Ş. Ş. (2010). The Anatoli Newspaper and the Heyday of the Karamanli Press. In E. Balta \& M. Kappler (Eds.), Cries and Whispers in Karamanlidika Books. Wiesbaden: Harrassowitz Verlag.

Şişman, C. (2015). Failed Proselytizers or Modernizers? Protestant Missionaries among the Jews and Sabbateans/Dönmes in the Nineteenth-century Ottoman Empire. Middle Eastern Studies, 51(6), 932-949.

Smith, A. D. (1986). The Ethnic Origins of Nations. New York, NY: Basil Blackwell. 
Smith, A. D. (1998). Nationalism and Modernism: A Critical Survey of Recent Theories of Nations. London; New York, NY: Routledge.

Stamatopoulos, D. (2006). From Millets to Minorities in the $19^{\text {th }}$ Century Ottoman Empire: An Ambiguous Modernization. In S. G. Ellis, G. Halfdanarson \& A. K. Isaacs (Eds.), Citizenship in Historical Perspective. Pisa: Pisa University Press.

Tanc, B. (2001). Where Local Trumps National: Christian Orthodox and Muslim Refugees since Lausanne. Balkanologie, 5(2), 273-289.

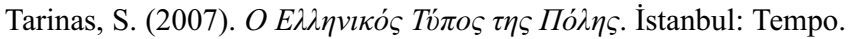

Tatsios, T. G. (1984). The Megali Idea and the Greek-Turkish War of 1897: The Impact of the Cretan Problem on Greek Irredentism, 1866-1897. New York, NY: East European Monographs, Boulder, CO, distributed by Columbia University Press.

Taylor, C. (1994). The Politics of Recognition. In A. Gutmann (Ed.), Multiculturalism. Princeton, NJ: Princeton University Press, pp. 25-73.

Thanailaki, P. (2004). The American Protestant Missionary Schools in Greece in the Nineteenth Century and Greek Orthodox Education. Greek Orthodox Theological Review, 49 $(1 / 2), 75-87$.

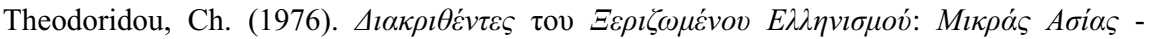

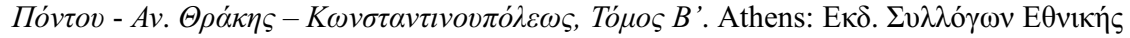

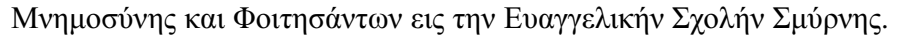

Thompson, P. (2000). The Voice of the Past. New York, NY: Oxford University Press.

Thornberry, P. (1991). International Law and the Rights of Minorities. New York, NY: Clarendon Press.

Tilly, C. (2005). Identities, Boundaries \& Social Ties. Boulder, CO: Paradigm Publishers.

Tsolainos, K. P. (1923). Greek Irredentism. Annals of the American Academy of Political and Social Science, 108, America's relation to the European Situation.

Tsolakidis, K. (2007). Belki Bir Gün Dönerim (B. Myisli, Trans.). Istanbul: Literatür Yayınları. (Original work published 2001).

Tuckerman, C. K. (1872). The Greeks of To-day. New York, NY: G. P. Putnam \& sons.

Tyler, A. (2008). Islam, the West, and Tolerance: Conceiving Co-existence. New York, NY: Palgrave MacMillan.

Valensi, L. (1997). Inter-communal Relations and Changes in Religious Affiliation in the Middle East (Seventeenth to Nineteenth Centuries). Comparative Studies in Society and History, 39(2), 251-269.

Van der Veer, P. (1994). Religious Nationalism. Berkeley, CA; Los Angeles, CA: University of California Press.

Van der Veer, P. (2003). Syncretism, Multiculturalism si Discursul Tolerantei (Syncretism, Multiculturalism and the Discourse of Tolerance). Journal for the Study of Religions and Ideologies, 2(5), 4-20.

Vassiadis, G. (2007). The Syllogos Movement of Constantinople and Ottoman Greek Education 1861-1923. Athens: Center for Asia Minor Studies.

Vryonis, S. Jr. (1971). The Decline of Medieval Hellenism in Asia Minor and the Process of Islamization from the Eleventh through the Fifteenth Century. Berkeley, CA; Los Angeles, CA: University of California Press.

Vryonis, S. Jr. (1982). Religious Change and Continuity in the Balkans and Anatolia from the Fourteenth through the Sixteenth Century. In S. Vryonis, Jr (Ed.), Byzantina Kai Metabyzantina: Studies on Byzantium, Seljuks, and Ottoman. Malibu: Undina Press.

Walder, D. (2011). Post-colonial Nostalgia: Writing, Representation, Memory. Abingdon; New York, NY: Routledge.

Walzer, M. (1997). On Toleration. New Haven, CO: Yale University Press. 
White, J. B. (1835). Observations on Heresy and Orthodoxy. London: J. Mardon.

Yesari, M. (2017). Bir Namus Meselesi. İstanbul: İstos Yayınları.

Yıldırım, O. (2006). Diplomacy and Displacement: Reconsidering Turco-Greek Exchange of Populations 1922-1934. New York, NY: Routledge.

Yıldırım, Y. \& Karpat, K. H. (Eds.). (2012). Osmanlı Hoşgörüsü. İstanbul: Timaş Yayınları.

Zandi-Sayek, S. (2012). Ottoman Izmir: the Rise of a Cosmopolitan Port, 1840/1880. London; Minneapolis: University of Minnesota Press.

Zürcher, E. J. (1998). The Ottoman Conscription System in Theory and Practice, 1844-1918. International Review of Social History, 43(3), 437-449.

\section{Electronic Resources}

A Balkan Tale. Retrieved January 15, 2015, from www.balkantale.com/

Halsall, P. (1996). Pact of Umar, $7^{\text {th }}$ century? The Status of non-Muslims under Muslim Rule. Medieval Sourcebook. Retrieved June 6, 2015, from http://legacy.fordham.edu/hal sall/source/pact-umar.asp

House of Commons Parliamentary Papers Online. (1865). Correspondence Respecting Protestant Missionaries and Converts in Turkey Presented to Both Houses of Parliament by Command of Her Majesty. London: Harrison and sons, 1865. Retrived May 21, 2015, from www.parlipapers.chadwyck.co.uk

"Prosorinon Politeuma Tes Hellados," The Epidaurus Constitution, 1822. Retrieved July 18, 2019, from www.hellenicparliament.gr/UserFiles/f3c70a23-7696-49db-9148f24dce6a27c8/syn06.pdf

Winter, J. Sites of Memory, Sites of Mourning. Retrieved April 13, 2015, from Open Yale courses Web site: http://oyc.yale.edu/history/hist-202/lecture-18 